\title{
Novel molecular, cytotoxical, and immunological study on promising and selective anticancer activity of Mung bean sprouts
}

\author{
Rand R Hafidh ${ }^{1,2+}$, Ahmed S Abdulamir ${ }^{3,2^{*}+}$, Fatimah Abu Bakar ${ }^{2 *}$, Farid Azizi Jalilian ${ }^{4,5}$, Faridah Abas ${ }^{6}$
} and Zamberi Sekawi ${ }^{4}$

\begin{abstract}
Background: The anticancer and immunomodulatory activity of mung bean sprouts (MBS) and the underlying mechanisms against human cervical and hepatocarcinoma cancer cells were explored.

Methods: MBS cytotoxicity and MBS-induced anticancer cytokines, TNF- $\alpha$ and IFN- $\beta$ from cancer cells, and immunological cytokines, IL-4, IFN- , and IL-10 from peripheral mononuclear cells (PMNC) were assessed by MTS and ELISA assays. Apoptotic cells were investigated by flow cytometry. The expression level of apoptotic genes (Bax, BCL-2, Capsases 7-9) and cell cycle regulatory genes (cyclin D, E, and A) and tumor suppressor proteins (p27, p21, and p53) was assessed by real-time QPCR in the cancer cells treated with extract IC50.

Results: The cytotoxicity on normal human cells was significantly different from HeLa and HepG2 cells, $163.97 \pm 5.73$, $13.3 \pm 0.89$, and $14.04 \pm 1.5 \mathrm{mg} / \mathrm{ml}$, respectively. The selectivity index (SI) was $12.44 \pm 0.83$ for HeLa and $11.94 \pm 1.2$ for HepG2 cells. Increased levels of TNF-a and IFN- $\beta$ were observed in the treated HeLa and HepG2 culture supernatants when compared with untreated cells. MBS extract was shown to be an immunopolarizing agent by inducing IFNy and inhibiting IL-4 production by PBMC; this leads to triggering of CMI and cellular cytotoxicity. The extract induced apoptosis, in a dose and time dependent manner, in treated HeLa and HepG2, but not in untreated, cells $(P<0.05)$. The treatment significantly induced cell cycle arrest in G0/G1 in HeLa cells. The percentage of cells in G0/G1 phase of the treated HeLa cells increased from $62.87 \pm 2.1 \%$, in untreated cells, to $80.48 \pm 2.97 \%$. Interestingly, MBS IC50 induced the expression of apoptosis and tumor suppressor related genes in both HeLa and HepG2 cells. MBS extract succeeded in inducing colk-inhibitors, p21, p53, and p27 in HeLa cells while it induced only p53 in HepG2 cells (P< 0.05). This is a clue for the cell type- specific interaction of the studied extract. These proteins inhibit the cyclin-cdk complexes apart from the presence of some other components that might stimulate some cyclins such as cyclin E, A, and D.
\end{abstract}

Conclusion: MBS extract was shown to be a potent anticancer agent granting new prospects of anticancer therapy using natural products.

\section{Background}

More attention has recently been given to the role of plant-derived compounds as promising nutraceuticals for controlling various disorders such as cardiovascular, neurological, neoplastic and immunological diseases [1].

\footnotetext{
* Correspondence: ahmsah73@yahoo.com; fatimah_upm_fst@yahoo.com ${ }^{\dagger}$ Equal contributors

${ }^{2}$ Institute of Bioscience, Universiti Putra Malaysia, 43400 UPM Serdang, Selangor Darul Ehsan, Malaysia

${ }^{3}$ Department of Microbiology, College of Medicine, Al-Nahrain University, Baghdad, Iraq

Full list of author information is available at the end of the article
}

The phytochemical compounds are found to be integral components of human diet. They are commonly present as constituents of flowering plants, particularly of food plants [2].

Studies verified that phytochemicals are able to alter the likelihood of carcinogenesis in every stage of cancer process in a way reducing the risk but usually in a favorable direction [3]. Interestingly, the main activity of these compounds depends on the fact that the exposure of human cells to a wide variety of chemoprotective compounds confers resistance against a broad set of carcinogens [4]. Much information exists nowadays on the

\section{Biomed Central}


antitumor action of plants, and many in vitro studies have concentrated on the direct and indirect actions of phytochemicals on tumor cells, and have found a variety of anticancer effects such as cell growth [5], kinase activity inhibition [6], apoptosis induction [7], and suppression of the secretion of matrix metalloproteinases, and tumor invasive behavior [8]. Furthermore, some studies reported the impairment of in vivo angiogenesis by dietary phytochemicals [9]. Therefore, the discovery of new anticancer agents from plant-derived substances is considered to be a highly promising approach in order to enrich the pharmaceutical field with effective drugs of lower side effects.

Besides, plants produce a vast number of natural products which have antimicrobial and immunomodulating potential as defense mechanisms for adapting to various environmental insults [10]. Many natural compounds have shown a significant ability to regulate immune responses [11]. Some of these phytochemicals with immunomodulating effects are isoflavonoids, indoles, phytosterols, polysaccharides, sesquiterpenes, alkaloids, glucans, tannins, a variety of vitamins and trace minerals that function as antioxidants and co-enzymes, and many other phytochemical substances [12].

It is clear that human immune response is a highly complex and extraordinarily sophisticated system involving both innate and adaptive mechanisms [13]. Immunomodulating activity refers to biological or pharmacological effects of compounds on humoral or cellular aspects of the immune response. In other words, immunomodulation is the process of modifying an immune response in a positive or negative manner by administration of a drug or a compound [11]. Although the field of study of immune enhancing compounds is relatively not new [14], natural products from plants represent a rich and promising source of novel molecules with immunomodulating properties that may augment a disease recovery alone or together with commercially known drugs.

For the first time in the field, the current study investigated the in vitro selective cytotoxic and immunomodulatory effects of mung bean sprout (Vigna radiata L.) methanol crude extracts on human cancer and peripheral mononuclear cells (PMNC), respectively. The rationale behind testing the anticancer and immunomodulatory effects of MBS extract is that first, MBS has not been assessed as anticancer or as immunomodulatory agent before, second, MBS is a germinating plant which usually possesses very high levels of antioxidants that are well known to act as potent anticancer and immunomodulatory agents. More in depth, this study explored thoroughly the underlying mechanisms of the newly discovered findings in the current study, namely, the novel anticancer and immunomodulatory effects of mung bean sprout (Vigna radiata L.) methanol extract by using cytological and molecular assays for assessing and measuring anticancer cytokines, cell cycle phases, percentage of apoptotic cells, expression level of cell cycle genes, tumor suppressor genes and apoptosis genes in MBS treated and untreated cancer cells. Moreover, PBMC-secreted cytokines, in response MBS extract exposure, were measured as an indicator for the immunomodulatory effect of MBS. Therefore, the ultimate goal of the current study is to find a natural anticancer product able to inhibit the proliferation of human cancer cell lines with high selectivity index, safe usage, and effective anticancer activity. This study has been patented in Malaysian intellectual property (MyIPO) under Malaysian patent application number PI2011001617 on 12th April 2011 (http://www. rmc.upm.edu.my/upmip/index.php?content=getfaculty\&ipi $\mathrm{d}=683$ \&ipdetailid $=671$ \&projectlead $=151$ \& cluster $=3 \&$ fac $=8$ ) and the current patented research has been considered for commercialization by University Putra Malaysia.

\section{Methods}

\section{Ethical approach}

The current study was conducted in compliance with Helsinki Declaration for ethical approaches of conducting scientific research. This study was approved by the ethical committee of University Putra Malaysia in Kuala Lumpur.

\section{Preparation of the MBS extract}

Fresh mung bean sprouts (MBS), devoid of any preservative antimicrobials was purchased from local markets in the State of Selangor, Malaysia. The growth of mung beans and the germination of the sprouts were done in Selangor State. The mung bean sprouts were left to dry in dark area for three days at room temperature $23-25^{\circ} \mathrm{C}$. After the dryness of sprouts, they were ground to powder. The ground powder was extracted 1:10 wt/v with 2.4 $\mathrm{M} \mathrm{HCl}$ acidified methanol (Merck, Darmstadt, Germany) to extract all, free and conjugated, components of phenolic compounds [15]; the ground powder was then soaked in dark area for three days at room temperature. The supernatant was collected after filtration and the fresh solvent was added to the plant material. The extraction procedure was repeated twice and the collected extracts were evaporated to dryness under vacuum at $40^{\circ} \mathrm{C}$ by using rotary evaporator. To remove the effect of the acidity from the crude extract, the crude extract of MBS was neutralized to exclude any $\mathrm{pH}$-related effect. The $\mathrm{pH}$ for MBS extract was neutral ranging from 6.8 to 7.0. The dried extracts were stored at $-18^{\circ} \mathrm{C}$ in a desiccant until further use.

\section{Preparation of stock extract}

The stock extract for MBS was prepared by redissolving the MBS extract powder in dimethyl sulfoxide (DMSO) 
0.1\%, (BIO BASIC INC., NY, USA). This concentration is usually non toxic to cell culture [16]. Moreover, this concentration was tested in the current study and was found to be non toxic to HeLa and HepG2 cells. The vitality of cells incubated with DMSO $(0.1 \%)$ was tested by MTT assay for different time intervals and was compared with that of control cells We found that both tested HeLa and HepG2 cells kept their vitality and freshness with DMSO concentration of $0.1 \%$ when compared to control cells with fresh medium [data not shown]. Afterwards, the dissolved suspension was centrifuged at $134 \mathrm{~g}$ for $10 \mathrm{~min}$ and filtrated by $0.22 \mu \mathrm{m}$ Millipore filters (Nalgene, UK). The stock was stored at $-20^{\circ} \mathrm{C}$ until it further use. The concentration of the stock extract was determined as required.

\section{Cancer cells propagation and cryopreservation}

Two human cancer cell lines, namely, cervix adenocarcinoma cells (HeLa; ATCC CCL-2) and hepatocellular carcenoma (HepG2; ATCC HB-8065), were used to evaluate the cytotoxic effects of MBS extract. Cells were propagated as monolayer under humidified $5 \% \mathrm{CO}_{2}$ atmosphere at $37^{\circ} \mathrm{C}$ in Roswell park memorial institute-1640 (RPMI-1640) culture medium w/L-glutamine (biowest, Florida, USA) supplemented with $10 \%$ fetal bovine serum (FBS) (Sigma, Germany), $50 \mathrm{U} / \mathrm{ml}$ penicillin-streptomycin (biowest, Florida, USA), and $2.5 \mu \mathrm{g} / \mathrm{ml}$ amphotericin B (biowest, Florida, USA). Part of the cells was cryopreserved for future work in liquid nitrogen $\left(-196^{\circ} \mathrm{C}\right)$ after suspending in RPMI-1640 cryospreserved medium supplemented with 10\% FBS, 20\% DMSO, $50 \mathrm{U} / \mathrm{ml}$ penicillin-streptomycin, and $2.5 \mu \mathrm{g} / \mathrm{ml}$ amphotericin B.

\section{Isolation of human peripheral blood mononuclear cells (PBMC)}

Human PBMC were isolated by density gradient centrifugation technique from heparinized whole blood. Thirty milliliters of fresh heparinized blood sample isolated from normal donor and diluted in phosphate buffer saline (PBS), (CALBIOCHEM, Darmstadt, Germany) were gently laid over $15 \mathrm{ml}$ of Ficoll Hypaque (GE Healthcare Bio-sciences $\mathrm{AB}$, Sweden) and were spun at $500 \mathrm{~g}$ for $20 \mathrm{~min}$ at $25^{\circ} \mathrm{C}$. PBMC were collected from the interface of spun blood samples and were washed three times with PBS by centrifugation at $500 \mathrm{~g}$ for $10 \mathrm{~min}$ at $4^{\circ} \mathrm{C}$. The supernatant was discarded and the cells were suspended in RPMI-1640 culture medium. Trypan blue solution 0.4\% (Sigma, Germany) was used to count the cells into an appropriate concentration and the viability of cells was checked; the required range of cells' viability is $95-99 \%$.

\section{MTS tetrazolium assay}

In order to determine the viable cells in proliferation or cytotoxicity assays, the MTS colorimetric method (the
Cell Titer $96^{\circledR}$ Aqueous One Solution Cell Proliferation Assay, Promega, USA) was used. MTS [3-(4,5dimethylthiazol-2-yl)-5-(3-carboxymethoxyphenyl)-2(4-sulfophenyl)-2H-tetrazolium] is reduced by dehydrogenase enzymes in metabolically active cells producing soluble colored formazan in tissue culture medium. The quantity of formazan products, measured at $490 \mathrm{~nm}$ absorbance after $4 \mathrm{~h}$ incubation time, is directly proportional to the number of living cells in the culture [17]. The absorbance was measured using a 96-well plate ELISA reader (Sunrise Basic Tecan, Grödig, Austria).

\section{Proliferation and cytotoxicity assays for PBMC}

Purified mononuclear cells, $2 \times 10^{5}$ cell/well, were cultured in quadruplicate in 96-well U-bottom tissue culture plates (Orange Scientific, Europe) with 2-fold serial dilutions of each extract in RPMI-1640 culture medium to a final volume of $200 \mu \mathrm{l} /$ well. The MBS extract concentrations ranged from 300 to $9.37 \mathrm{mg} / \mathrm{ml}$. The negative control wells, in quadruplicates, contained PBMC in RPMI-1640 culture medium (200 $\mu \mathrm{l} /$ well). The positive control wells, in quadruplicates, contained PBMC with Concavalin A (Con A), $(10 \mu \mathrm{g} / \mathrm{ml})$, a T-cell specific mitogen (Sigma, Germany), at a final volume of $200 \mu \mathrm{l} /$ well. The plates were used to assess the cytotoxicity or the stimulatory effect of the extracts on PBMC proliferation. Cultures were incubated in humidified $5 \% \mathrm{CO}_{2}$ atmosphere for $72 \mathrm{~h}$ at $37^{\circ} \mathrm{C}$. After $72 \mathrm{~h}, 20 \mu \mathrm{l}$ of MTS solution with $100 \mu \mathrm{l}$ of RPMI-1640 culture medium were added to each well. The plates were incubated for four hours at the same conditions. Later, the absorbance was measured at $490 \mathrm{~nm}$ (reference $690 \mathrm{~nm}$ ) using a 96-well plate ELISA reader. Each experiment was repeated for three times with four wells per dilution in each run.

The extract effect to stimulate PBMC proliferation was calculated using the following formula:

$$
\text { Proliferation } \%=[(\mathrm{ODt} / \mathrm{ODc})-1] \times 100
$$

Where (ODt) indicates the optical density of the tested extract and (ODc) indicates the optical density of the negative control [18].

On the other hand, the data of the extract cytotoxicity against PBMC was calculated using the following formula:

$$
\text { Cytotoxicity } \%=[1-(\mathrm{ODt} / \mathrm{ODc})] \times 100
$$

Where (ODt) indicates the optical density of the tested extract and (ODc) indicates the optical density of the negative control. Accordingly, the concentration of 50\% inhibition (CC50) was the concentration that achieved $50 \%$ cytotoxicity against PBMC [19]. 


\section{Cytotoxicity on human cancer cell lines}

Cytotoxicity assay was performed according to the established method of Mena-Rejon et al. (2009), where $1 \times \mathrm{k} 10^{5}$ cell/well viable HeLa and HepG2 cells were grown in RPMI-1640 culture medium in 96-well flat-bottom tissue culture plates (Orange Scientific, Europe). The plates were incubated in humidified $5 \% \mathrm{CO}_{2}$ for $24 \mathrm{~h}$ at $37^{\circ} \mathrm{C}$. When cells reached $>80 \%$ confluence, the medium was replaced with $200 \mu \mathrm{l} /$ well of 2-fold serial dilutions of MBS extract from 164 to $10.25 \mathrm{mg} / \mathrm{ml}$ prepared in RPMI-1640 maintenance medium (with $2 \%$ FBS). The concentration of MBS extract was $328 \mathrm{mg} / \mathrm{ml}$. The negative control wells contained DMSO (0.1\%) in RPMI-1640 maintenance medium with final volume of $200 \mu \mathrm{l} /$ well. All the plates were incubated in humidified $5 \% \mathrm{CO}_{2}$ for $24 \mathrm{~h}$ at $37^{\circ} \mathrm{C}$. Later, all the wells' contents were removed and replaced with $200 \mu \mathrm{l} /$ well of RPMI-1640 maintenance medium. The plates were reincubated for $48 \mathrm{~h}$ at the same conditions. Afterwards, 20 $\mu \mathrm{l}$ of MTS solution with $100 \mu \mathrm{l}$ of RPMI-1640 culture medium were added to each well. The plates were incubated for four hours in the same conditions. The absorbance was measured at $490 \mathrm{~nm}$ (reference $690 \mathrm{~nm}$ ) using a 96-well plate ELISA reader. Each experiment was repeated for three times with four wells per dilution in each run [20].

The concentration of the extract that killed $50 \%$ of the cells (IC50) was calculated using the following formula:

$$
\text { Cytotoxicity } \%=[1-(\mathrm{ODt} / \mathrm{ODc})] \times 100
$$

Where (ODt) indicates the optical density of the tested extract and (ODc) indicates the optical density of the negative control. The selectivity index (SI) was the ratio of CC50 (cytotoxicity on PBMC) to the IC50 (cytotoxicity on human cancer cells), [19].

\section{Cytokine production by PBMC}

In order to evaluate the immunomodulatory effect of MBS extract, the cytokine level produced from PBMC after treatment with MBS extract was investigated. PBMC at $2 \times 10^{5}$ cell/well were cultured, in triplicates, in 96-well Ubottom tissue culture plates with 2-fold serial dilutions of the extract in RPMI-1640 culture medium to a final volume of $200 \mu \mathrm{l} /$ well. The extract concentrations ranged from 100 to $3.12 \mathrm{mg} / \mathrm{ml}$. The negative control wells, in triplicates, contained $200 \mu \mathrm{l} /$ well of PBMC in RPMI-1640 culture medium. After $24 \mathrm{~h}$ of incubation at $37^{\circ} \mathrm{C}$ in humidified $5 \% \mathrm{CO}_{2}$ atmosphere, the plates were centrifuged at $300 \mathrm{~g}$ for $10 \mathrm{~min}$. The supernatant was collected and centrifuged at $1000 \mathrm{~g}$ for $10 \mathrm{~min}$ to be ready to determine the cytokine level produced into the medium [21].

\section{Cytokine production by human cancer cell lines}

The level of anticancer cytokines, IFN- $\beta$ and TNF- $\alpha$, was investigated in treated and untreated HeLa and
HepG2 cells. HeLa and HepG2 cells at $1 \times 10^{5}$ cell/well were grown in RPMI-1640 culture medium in 96-well flat-bottom tissue culture plates in a humidified $5 \% \mathrm{CO}_{2}$ atmosphere for $24 \mathrm{~h}$ at $37^{\circ} \mathrm{C}$. Later, serial 2-fold dilutions of MBS 10 to $0.31 \mathrm{mg} / \mathrm{ml}$ prepared in RPMI-1640 maintenance medium were added to the cells, in triplicates, to a final volume of $200 \mu \mathrm{l} /$ well. The MBS extract stock concentration was $20 \mathrm{mg} / \mathrm{ml}$. The negative control wells, in triplicates, contained cells with RPMI-1640 maintenance medium only with final volume of $200 \mu \mathrm{l} /$ well. The plates were incubated for $48 \mathrm{~h}$ at the same conditions. Afterwards the supernatants from all the wells were removed and centrifuged at $1000 \mathrm{~g}$ for $10 \mathrm{~min}$ to be ready for the ELISA technique [22].

\section{Measuerment of cytokines produced by PBMC and cancer cells}

The levels of immunomodulatory cytokines, IL-2, IL-4 and IFN- $\gamma$, in the PBMC culture supernatant with and without extract treatment, and the levels of anticancer cytokines, IFN- $\beta$ and TNF- $\alpha$, in the supernatant of cultured treated and non-treated cancer cells, were measured. The procedures pursued were according to the manufacturers' instructions of each kit. For IL-2 and IL4 , the used kit was human enzyme immunometric assay (EIA) kits (Cayman, USA), for IFN- $\gamma$, a human interferon gamma ELISA kit (abcam, USA) was used, and for anticancer cytokines, human IFN- $\beta$ ELISA (abcam, USA) and TNF- $\alpha$ human enzyme immunometric assay (EIA) kits (Cayman, USA) were used.

Each microtiter plate was already coated with monoclonal antibodies specific for the corresponding cytokine. The standards of IL- 2 and IL-4 were reconstituted in the same matrix of the samples, namely RPMI-1640 medium plus each 2-fold serial dilution of the extract; this step is needed to match the color effect of unpurified samples that might persist even after the subsequent washing steps. Accordingly, a standard curve was made for each dilution of the extracts used. The IL- 2 or IL-4 standards were prepared as 2-fold serial dilutions ranging from 250 to $3.9 \mathrm{pg} / \mathrm{ml}$ in eight tubes of $15 \mathrm{ml}$ capacity (Orange Scientific, Europe); the eighth tube contained zero concentration of IL-2 or IL-4 standard.

For IFN- $\gamma$, standards were freshly prepared by reconstituting in the standard diluents buffer to give a stock concentration of $400 \mathrm{pg} / \mathrm{ml}$. Two hundred microliter of this stock was added, in triplicates, to the already coated microtiter plates provided by the kit. Each plate was coated with monoclonal IFN- $\gamma$ specific antibodies. From stock wells, serial 2-fold dilutions of IFN- $\gamma$ standard were prepared by diluting the standard in a matrix similar to that of the samples which is RPMI-1640 culture medium plus each dilution of the extracts used. This step is needed to match the color effect of unpurified samples that might persist even 
after the subsequent washing steps. Accordingly, a standard curve was made for each dilution of the extracts used. IFN- $\gamma$ standard concentrations ranged from 400 to 12.5 $\mathrm{pg} / \mathrm{ml}$; and the last standard contained zero concentration of IFN- $\gamma$ standard in the sample matrix.

For immunomodulatory cytokines, IL-2, IL-4, IFN- $\gamma$, and anticancer cytokines, IFN- $\beta$ and TNF- $\alpha$, one hundred $\mu \mathrm{l}$ of standards, samples, and conjugates were all assayed as triplicates. For IL-2 and IL-4, the absorbance was measured at $412 \mathrm{~nm}$ (reference $690 \mathrm{~nm}$ ) using a 96-well plate ELISA reader. The assay was repeated for three times for each sample. The concentrations of samples' IL-2 and IL-4 were determined by extrapolating their OD values with that of the generated standard curves. For IFN- $\gamma$, the absorbance was measured at $450 \mathrm{~nm}$ (reference $620 \mathrm{~nm}$ ) by ELISA reader. The sample concentrations were determined by extrapolating OD values to IFN- $\gamma$ concentrations using the generated linear standard curves (the average absorbance on the vertical axis versus the corresponding IFN- $\gamma$ standard concentration on the horizontal axis). One hundred $\mu \mathrm{l}$ of sample, conjugates and substrate-chromogen were used according to the guidelines of the kits manufacturer. Later, the absorbance was measured at $412 \mathrm{~nm}$ (reference 690 $\mathrm{nm}$ ) and at $450 \mathrm{~nm}$ (reference $620 \mathrm{~nm}$ ) using a 96-well plate ELISA reader for TNF- $\alpha$ and IFN- $\beta$ plates, respectively. The assay was repeated for three times for each sample. The concentrations of the cytokines were determined by extrapolating their OD values with that of the generated standard curves.

\section{Analysis of apoptosis}

\section{Flow cytometry analysis for cell apoptosis}

Flow cytometry can rapidly quantify and evaluate the properties of apoptotic cells. It can give information on the ratio of apoptotic cells, based on the cellular size or DNA contents. It is well known that several differences are present between apoptotic cells and normal cells. These differences can be utilized by flow cytometric techniques for apoptosis detection [23]. The cells (HeLa and HepG2) were seeded $\left(1 \times 10^{5}\right.$ cell/well $)$ in 6-wells tissue culture plates and were incubated in a humidified 5\% $\mathrm{CO}_{2}$ atmosphere for $24 \mathrm{~h}$ at $37^{\circ} \mathrm{C}$. The medium was then replaced with RPMI-1640 maintenance medium with or without MBS extract and was incubated for further $24 \mathrm{~h}$ at the same conditions. The cell treatment was divided into two groups. In the first group (dose-dependent group), the effect of three 2-fold serial dilutions of the extract (concentration $>$ IC50 > concentration) was investigated regarding the level of apoptosis, if any, after a fixed time. The concentrations of MBS extract were 26.6, 13.3, and $6.65 \mathrm{mg} / \mathrm{ml}$ with HeLa cells and were 28.08, 14.04, and $7.02 \mathrm{mg} / \mathrm{ml}$ with HepG2 cells. In the second group (time-dependent group), the IC50 of MBS extract was used to investigate the level of cells' apoptosis as well as cell cycle arrest after different time intervals of incubation with the extract. For the first group, after $24 \mathrm{~h}$, the cells were harvested and transferred to $15 \mathrm{ml}$ tubes. All of the tubes were centrifuged at $190 \mathrm{~g}$ for $10 \mathrm{~min}$. The supernatants were discarded and the pellets were washed two times by cold PBS. Later, the pellets were resuspended in 70\% ice-cold ethanol with PBS, 1:10 v/v, and were incubated for $2 \mathrm{~h}$ at $-20^{\circ} \mathrm{C}$. Then, all the supernatants were aspirated after centrifugation at $500 \mathrm{~g}$ for $10 \mathrm{~min}$. The washing step by PBS was repeated and the supernatants were aspirated. The pellets were resuspended in $500 \mu \mathrm{l}$ of DNA staining solution containing $25 \mu \mathrm{l}$ of propidium iodide (PI) $1 \mathrm{mg} / \mathrm{ml}$ (MP Biomedicals, LLC, IIIKrick, France), a double-stranded nucleic acid intercalating agent, and $50 \mu \mathrm{l}$ Ribonuclease A from bovine pancrease $(1 \mathrm{mg} / \mathrm{ml})$, (Sigma, Germany) in PBS. All the tubes were incubated on ice in dark area for $30 \mathrm{~min}$ [24]. The assay was measured in duplicate for each sample. The propidium iodide fluorescence of individual nuclei was measured using CyAn ADP apparatus (BECKMAN COULTER, USA). The software Summit (V4.3) was used to analyze the flow cytometry results.

For the second group of the flow cytometry analysis, the stock extract was prepared and the same method mentioned earlier for the first group was used except for the following differences: the IC50 for MBS extract with HeLa and HepG2 cells was used to treat the cells. The IC50 of MBS extract was $13.3 \mathrm{mg} / \mathrm{ml}$ with $\mathrm{HeLa}$ cells and $14.04 \mathrm{mg} / \mathrm{ml}$ with HepG2 cells. The group was subdivided into seven treatments $(8,12,16,20,24,48$ and $72 \mathrm{~h})$. The assay was measured in duplicate for each sample in the specific time of treatment.

\section{Detection of apoptosis- and cell cycle arrest- related genes by real time quantitative $P C R$ ( $q R T-P C R)$}

The current trend of research uses advanced techniques in molecular biology to study the apoptosis- and cell cycle arrest- related genes' expression such as Bcl-2 family, members of caspase family, tumor suppressor proteins, and cyclins. Nowadays, by using the reverse transcription-polymerase chain reaction (RT-PCR), the scientists can demonstrate the level of mRNA expression of apoptosis and cell cycle proteins even though they are expressed only in a small cell population in tissues [25].

\section{RNA extraction}

The cells (HeLa and HepG2) were seeded $\left(1 \times 10^{5}\right.$ cell/ well) in 6-wells tissue culture plates and were incubated in a humidified $5 \% \mathrm{CO}_{2}$ atmosphere for $24 \mathrm{~h}$ at $37^{\circ} \mathrm{C}$. The medium was then replaced with RPMI-1640 maintenance medium either alone or with MBS extract, in duplicates, and the medium was incubated at the same conditions. The IC50 for MBS extract against each type of cells was used. The IC50 of MBS extract was $13.3 \mathrm{mg} / \mathrm{ml}$ with HeLa 
cells and $14.04 \mathrm{mg} / \mathrm{ml}$ with HepG2 cells. After determining the best timing for studying the apoptosis and cell cycle arrest by flow cytometry, treatment of cells with extract for 12,16 , and $20 \mathrm{~h}$ was conducted. At the end of 12,16 , or $20 \mathrm{~h}$ of extract treatment, the cells were harvested and transferred to $15 \mathrm{ml}$ tubes. After centrifuging the tubes at $134 \mathrm{~g}$ for $5 \mathrm{~min}$, the supernatants were discarded. The pellets were resuspended in PBS and were washed for four times.

It is noteworthy to mention that one of the most important steps preceding the synthesis of good quality cDNA is the isolation of intact (undegraded) total RNA from cultured cells or tissues [25]. Total RNA was isolated using GF-1 kit (Vivantis Technologies, Malaysia). According to the manufacturer's protocol for RNA isolation from cell culture, $1 \times 10^{7}$ cells were precipitated in $1.5 \mathrm{ml}$ microtubes (Eppendrof, Hamberg, Germany) at $1000 \times \mathrm{g}$ for $5 \mathrm{~min}$. The cell pellets were resuspended in $700 \mu \mathrm{l}$ of lyses buffer (Buffer TR) with vigorous mixing by vortexing. This buffer is specially formulated to inactivate cellular RNases together with cell lysis. Later, the lysed cells were transferred to homogenization columns assembled in a collection tubes. The columns were centrifuged at $10.000 \times \mathrm{g}$ for $2 \mathrm{~min}$. The flow-though was saved and equal volume of $80 \%$ ethanol $(700 \mu \mathrm{l})$ was added. The lysed cells were mixed thoroughly by pipetting and were transferred into RNA binding columns assembled in collection tubes. RNA binding columns were centrifuged at $10.000 \times \mathrm{g}$ for $1 \mathrm{~min}$ and the flow-though was discarded. The columns were washed by adding $500 \mu$ of washing buffer and were centrifuged at $14.000 \times \mathrm{g}$ for $1 \mathrm{~min}$. The flow-though was discarded and all of the DNA fragments were removed by DNase I treatment. Seventy microlitter of DNase I Digestion Mix were added to RNA binding columns and were incubated at room temperature for $15 \mathrm{~min}$. DNase I Digestion Mix was composed of DNase I $(7 \mu \mathrm{l})$, digestion buffer $(56 \mu \mathrm{l})$, and digestion enhancer $(7 \mu \mathrm{l})$. Then, $500 \mu \mathrm{l}$ of inhibitor removal buffer were added to the columns which were centrifuged at $14.000 \times \mathrm{g}$ for $1 \mathrm{~min}$. The columns were washed with $500 \mu \mathrm{l}$ washing buffer for two times with centrifugation at $10.000 \times \mathrm{g}$ for $1 \mathrm{~min}$ for each run. Further centrifugation at $10.000 \times \mathrm{g}$ for $1 \mathrm{~min}$ was done to remove any traces of buffer. Total RNA was collected by placing the columns into new $1.5 \mathrm{ml}$ microtubes with $60 \mu \mathrm{l}$ RNase-free water addition and standing for $1 \mathrm{~min}$. The microtubes were centrifuged at $10.000 \times \mathrm{g}$ for $1 \mathrm{~min}$. RNA quality and quantity were determined by Life Science UV/Vis Spectrophotometer, DU Series 700 (BECKMAN COULTER, USA).The isolated RNA was stored at $-80^{\circ} \mathrm{C}$ and was ready for use in downstream application, namely, qRT-PCR.

\section{Real time quantitative RT-PCR}

One microgram of the isolated RNA from each sample was reverse-transcribed by iScript ${ }^{\mathrm{TM}}$ cDNA Synthesis Kit
(BIO-RAD, Hercules, Canada). According to the manufacturer's protocol, $4 \mu \mathrm{l}$ of $5 \times$ iScript reaction mix were mixed with $1 \mu \mathrm{l}$ iScript reverse transcriptase and $15 \mu \mathrm{l}$ of RNA template in $1.5 \mathrm{ml}$ microtubes to give final volume of $20 \mu \mathrm{l}$ per reaction. The complete reaction mix was incubated for $5 \mathrm{~min}$ at $25^{\circ} \mathrm{C}$ then for $30 \mathrm{~min}$ at $42^{\circ} \mathrm{C}$ using Thermo Bath, ALB64 (FINEPCR, Seoul, Korea). The incubation temperature was increased to $85^{\circ} \mathrm{C}$ for $5 \mathrm{~min}$. Finally, cDNA was stored at $-80^{\circ} \mathrm{C}$ for qRT-PCR reaction.

Real-time quantitative PCR reaction was conducted using SsoFast ${ }^{\mathrm{TM}}$ EvaGreen $^{\circledR}$ Supermix (BIO-RAD, Hercules, Canada). Depending on the manufacturer's protocol, $10 \mu \mathrm{l}$ of $1 \mathrm{x}$ SsoFast EvaGreen supermix were mixed with $7 \mu \mathrm{l}$ RNase/DNase free water. One microlitter of forward primer $(500 \mathrm{nM})$ and $1 \mu \mathrm{l}$ of reverse primer $(500 \mathrm{nM})$ were added to the previous mix (Table 1). Finally, $1 \mu \mathrm{l}$ of cDNA template corresponding to $50 \mathrm{ng}$ of total RNA was added. The PCR reaction $(20 \mu \mathrm{l})$ was run for 40 cycles using $\mathrm{CFX}^{\mathrm{TM}}{ }^{\mathrm{TM}}$ RealTime System (BIO-RAD, Hercules, Canada). Cycling conditions were $95^{\circ} \mathrm{C}$ for $3 \mathrm{~min}, 95^{\circ} \mathrm{C}$ for $10 \mathrm{sec}, 55-61^{\circ} \mathrm{C}$ for $30 \mathrm{sec}$, and $72^{\circ} \mathrm{C}$ for $20 \mathrm{sec}$. PCR reaction for cDNA templates from untreated HeLa and HepG2 cells were used as negative controls. The PCR reaction was run in triplicate for each target gene. PCR reaction mix without cDNA template was used to detect any contamination. At the end of the amplification, measurement of Eva Green fluorescence was done continuously with the conduction of the melting curve analysis by slow heating at $0.5^{\circ} \mathrm{Cs}^{-1}$ increments from 70 to $95^{\circ} \mathrm{C}$, with continuous fluorescence collection. Accordingly, a melting curve was generated at the end of the PCR amplification for monitoring the specificity of PCR reaction. Melting curve analysis of the negative first derivative was pursued. Betaactin was used as a housekeeping gene (reference gene) to normalize the mRNA expression of target genes. Because PCR efficiency may vary among different primers, the calculation of PCR primers' efficiency is essential for obtaining accurate measurements of the relative expression of the mRNA of target genes [26]. For this reason, a standard curve was created by diluting template cDNA of each single primer used in this study. The cDNA template for each primer was serially diluted $\left(10^{-1}\right.$ to $\left.10^{-7}\right)$; each dilution serves as a standard. In this reaction, cDNA template was used from samples with high expression to the target of interest. The amplification efficiency can be obtained by analyzing the slope of the log-linear portion of the standard curve. When the logarithm of the initial template concentration is plotted on the $\mathrm{x}$ axis and the threshold cycle $\left(C_{t}\right)$ is plotted on the y axis, PCR efficiency is calculated according to the following equation [26]:

$$
\text { PCR efficiency }=10^{-1 / \text { slope }_{-1}}
$$


Table 1 Primers used in Real-Time quantitative PCR analysis (Vivantis Technologies, Malaysia)

\begin{tabular}{lll}
\hline & Forward primer & Reverse primer \\
\hline Bax & CAC CAG CTC TGA GCA GAT & GCG AGG CGG TGA GCA CTC \\
BCL-2 & TAC CTG AAC CGG CAC CTG & GCC GTA CAG TTC CAC AAA GG \\
Caspase 7 & GTC TCA CCT ATC CTG CCC TCA & TTC TTC TTC TGC CTC ACT GTC \\
Caspase 8 & GAA AAG CAA ACC TCG GGG ATA C & CCA AGT GTG TTC CAT TCC TGT C \\
Caspase 9 & CCA GAG ATT CGC AAA CCA GAG G & GAG CAC CGA CAT CAC CAA ATC C \\
Cyclin D & AGA CCT GCG CGC CCT CGG TG & GTA GTA GGA CAG GAA GTT GTT C \\
Cyclin E & CTC CAG GAA GAG GAA GGC AA & TCG ATT TTG GCC ATT TCT TCA \\
Cyclin A & GTC ACC ACA TAC TAT GGA CAT G & AAG TTा TCC TCT CAG CAC TGA C \\
p21 & GTG ATT GCG ATG CGC TCA TG & TCT CTT GCA GAA GAC CAA TC \\
p27 & GTC TAA CGG GAG CCC TAG CC & CTA ACC CCG TCT GGC TGT CC \\
p53 - -actin (reference gene) & GAA CAT GAG TTा TाT ATG GC \\
\hline
\end{tabular}

Note: all primers are listed $5^{\prime}-3^{\prime}$.

The software BIO-RAD CFX Manager (V 1.1.308) was used to relatively quantify the target genes according to the following equation [27]:

$$
\text { Ratio }=\left(\mathrm{E}_{\text {target }}\right)^{\Delta \mathrm{Ct} \text { target(control-sample })} /\left(\mathrm{E}_{\mathrm{ref}}\right)^{\Delta \mathrm{CtRef}(\text { control-sample })}
$$

In which (E): represents the amount of fold change per cycle per gene. Ref: represents the reference gene. Target: represents the target gene.

It has been well known that the ratio of $\mathrm{Bax}$ to $\mathrm{Bcl}-2$ determines, in part, the susceptibility of cells to death signals [28]. Therefore, the Bax to Bcl-2 ratio was calculated using the following equation:

$$
\begin{aligned}
& \mathrm{Bax} / \mathrm{Bcl}-2 \text { ratio } \\
& =(\text { mean PCR efficiency for } \mathrm{Bax} \text { and } \mathrm{Bcl}-2)^{(\mathrm{CtBcl} 2-\mathrm{CtBax})}
\end{aligned}
$$

\section{Data analysis}

All the data in the current study are shown as mean $\pm 2 \mathrm{SE}$. The selectivity index (SI) was determined by using the ratio of CC50 to IC50. The data analysis was conducted by using SPSS software version (12.0.0.2). The effect of the tested extract on the inhibition of cell growth was evaluated by using 95\% confidence intervals. IC50 and CC50 values were calculated using linear regression index equations. The statistically different effects of the extract on the ability of PBMC, HeLa and HepG2 cells to synthesize selected cytokines were compared with the control groups using the Student's $t$-test. For flow cytomteric analysis, R2 fraction represented sub-G apoptotic cells; moreover, the percentage of cells at different cell cycle phases was calculated from the total cells minus apoptotic cells. For quantitative real time PCR, the up- or down- regulation of mRNA expression of selected genes was measured as expression fold changes in term of mean \pm 2 SD. The significance of up- or down- regulation of the normalized mRNA expression of selected genes was determined by comparing the mean $\pm 2 \mathrm{SD}$ of any up- or down- regulation with the mean $\pm 2 \mathrm{SD}$ of control (untreated cells), equal to $1 \pm 2 \mathrm{SD}$. $\mathrm{P}$ values less than 0.05 were considered significant.

\section{Results}

\section{Cytotoxicity on human cancer cells}

The results of the current study revealed that the cytotoxic effects of MBS extract on normal human cells (PBMC) was significantly different $(\mathrm{P}<0.05)$ from that on human cancer cells (Table 2). The cytotoxic effect of MBS extract on PBMC, expressed as CC50, was 163.97 $\mathrm{mg} / \mathrm{ml}$ while its IC50 on HeLa cells was $13.3 \mathrm{mg} / \mathrm{ml}$ and on HepG2 cells was $14.04 \mathrm{mg} / \mathrm{ml}$. These findings revealed that MBS extract required high concentrations to be cytotoxic on normal human cells (Figure 1) while only low concentrations were enough to give the same effect on human cancer cells (Figure 2). These results

Table 2 The cytotoxic effect of MBS extract on cancer cell lines

\begin{tabular}{lllllll}
\hline Extract & Cancer cell line & ${ }^{\mathbf{a}} \mathbf{C C 5 0} \mathbf{~ m g} / \mathbf{m l}$ & ${ }^{\mathbf{b}} \mathbf{C} \mathbf{5 0} \mathbf{~ m g} / \mathbf{m l}$ & $\mathbf{P}$ value & $\mathbf{P}<\mathbf{0 . 0 5}$ & ${ }^{\mathbf{c}} \mathbf{S I}$ \\
\hline MBS & HeLa & $163.97 \pm 5.73$ & $13.3 \pm 0.89$ & $6.54539 \mathrm{E}-06$ & Significant & $12.44 \pm 0.83$ \\
& HepG2 & $163.97 \pm 5.73$ & $14.04 \pm 1.5$ & $7.25478 \mathrm{E}-06$ & Significant & $11.94 \pm 1.2$ \\
\hline
\end{tabular}

Note: ${ }^{\mathrm{a}}$ The results of CC50 (on peripheral blood mononuclear cells) are shown as mean $\pm 2 \mathrm{SE} .{ }^{\mathrm{b}}$ The results of IC50 (on cancer cell lines) are shown as mean $\pm 2 \mathrm{SE}$. 'Selectivity index represents the ratio of CC50/IC50. The results are shown as mean \pm 2 SE. 


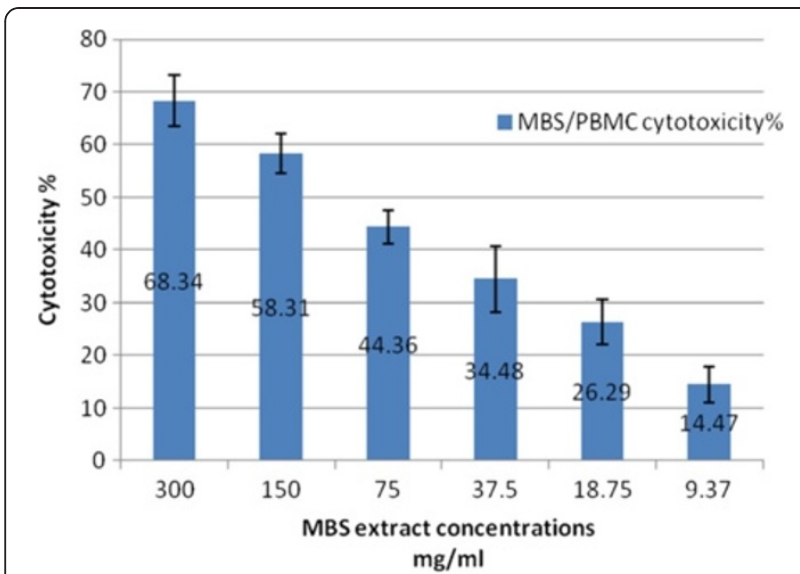

Figure 1 The percentage of PBMC death after treatment with 2-fold serial dilutions of MBS extracts in term of mean $\pm 2 \mathrm{SE}$ (confidence interval $\mathrm{Cl}$ 95\%).

reflected the good selectivity and safety of these extracts as cytotoxic agents (Figure 3).

The cytotoxicity of MBS extract on PBMC, HeLa and HepG2 cells was dose dependent. In other words, the cytotoxicity of MBS extract decreased with higher dilutions, lower concentrations, of the extract. The significant differences of MBS cytotoxicity were supported by the results of the selectivity index (SI) which is the ratio of the highest concentration that causes $50 \%$ death to normal cells (CC50) to the lowest concentration that causes $50 \%$ death to cancer cells (IC50). The SI values of MBS extract demonstrated effective SI values on HeLa cells, 12.44, and HepG2 cells, 11.94 (Table 2). The cytotoxic effect of MBS extract showed no significant difference between HeLa and HepG2 cells.

\section{Non-specific immune response by PBMC}

The results of the proliferation assay of PBMC treated with MBS extract were not significant. According to the formula of the proliferative \%, the data of the proliferation \% for PBMC were the same for that of the cytotoxicity $\%$ but in negative values (Figure 1). The results showed that MBS extract has no proliferative effect on PBMC when compared to the mitogenic effect of Con A (proliferative $\%=63.89 \pm 4.7$ ). Instead, MBS extract showed a cytotoxic effect on these cells but this cytotoxic effect is of far less impact than that on the cancer cells.

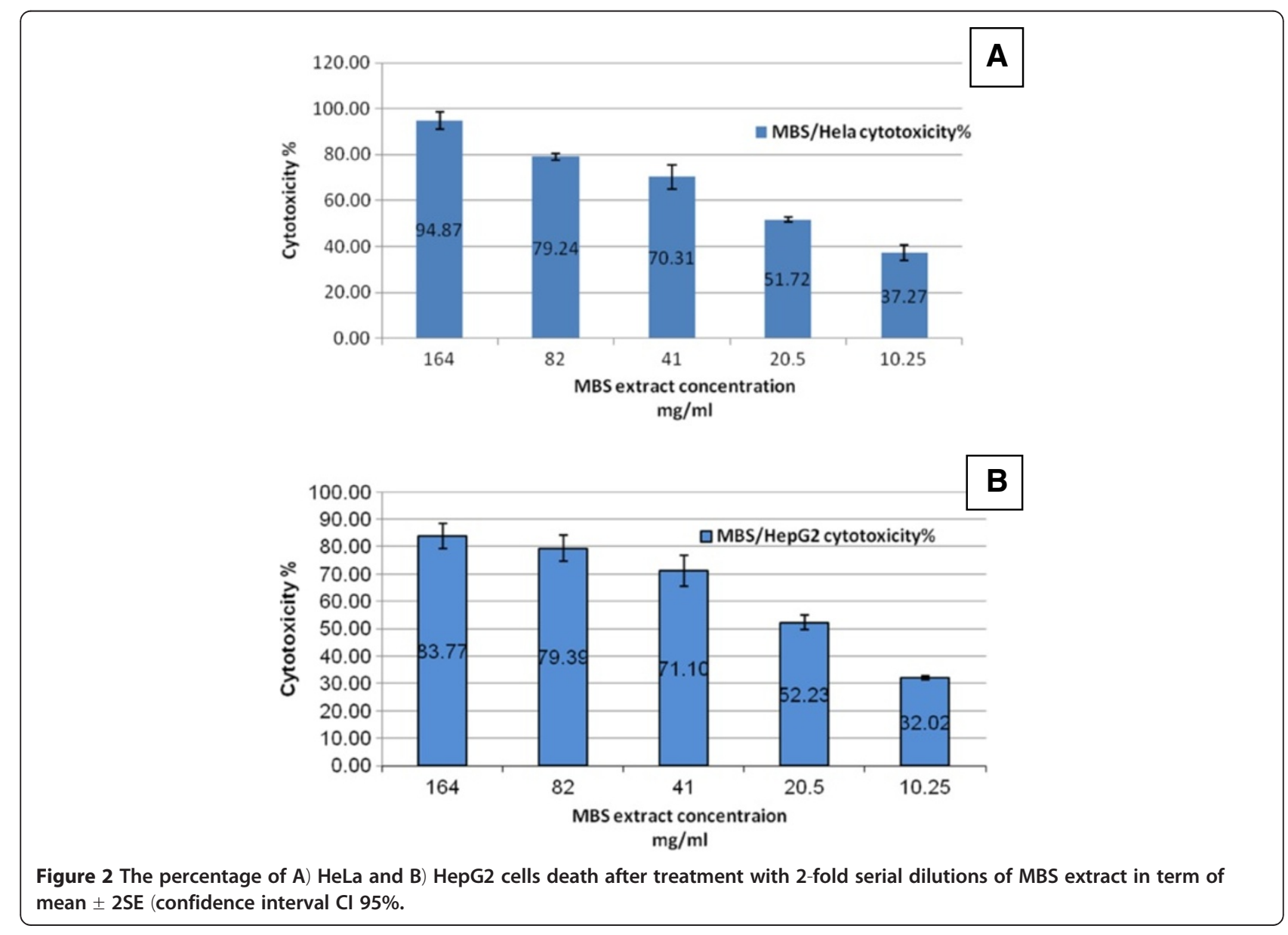



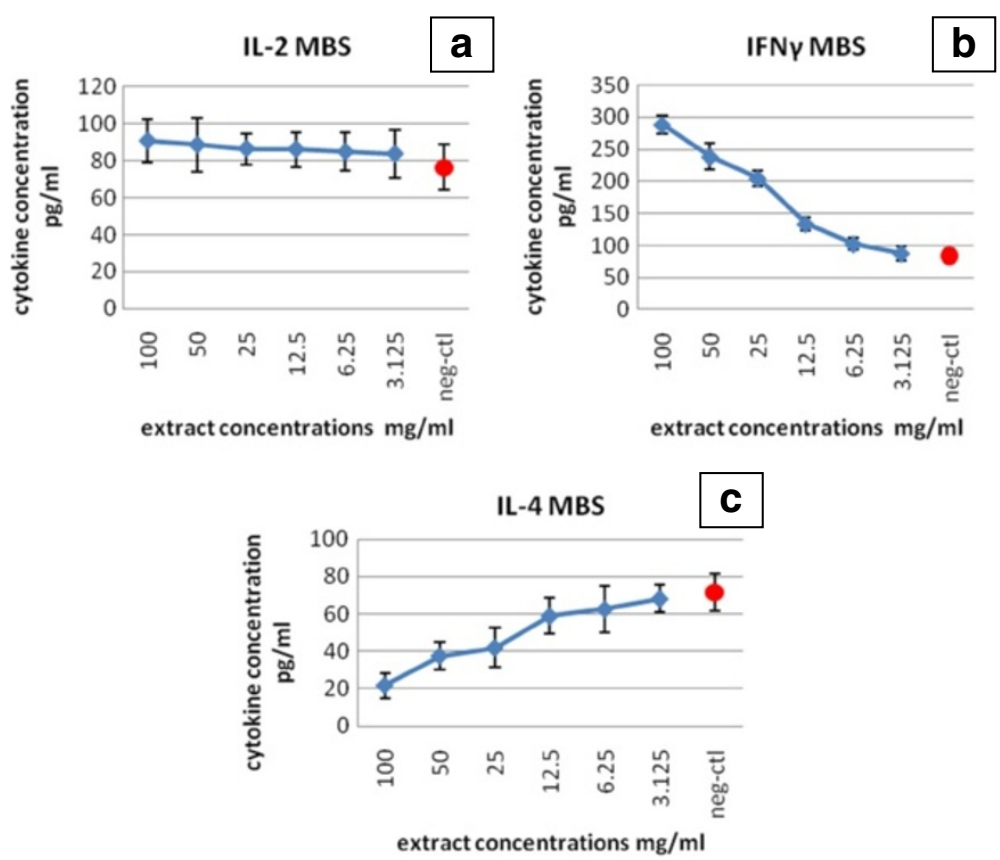

Figure 3 Figures demonstrate the level of the produced cytokines, in comparison with negative control (neg-ctl), in culture supernatant of peripheral blood lymphocyte cell after treatment with mung bean sprout extract (MBS): a) IL-2, b) IFN- $\gamma$ and c) IL-4.

Accordingly, PBMC were treated with extract concentrations less than that of the CC50 (Figure 3) to avoid any minute cytotoxic effect by the extract and to allow cytokines production, if any. The cytokine production assay showed that there was no significant difference $(P>0.05)$ in the level of IL-2 production between the treated PBMC and the control group, the untreated PBMC. Thus, PBMC treated with MBS extract did not produce IL-2 in a significant amount when compared with untreated PBMC (Table 3). However, there was a significant difference $(P<0.05)$ in the level of IFN- $\gamma$ in PBMC culture supernatants of MBStreated and MBS-untreated cells.. It was shown that IFN- $\gamma$

Table 3 The level of IL-2 produced by PBMC after treatment with different concentrations of MBS extract

\begin{tabular}{|c|c|c|c|c|}
\hline \multirow[b]{2}{*}{$\begin{array}{l}\text { Extract } \\
\text { concentrations } \\
\mathrm{mg} / \mathrm{ml}\end{array}$} & \multicolumn{2}{|c|}{ IL-2 concentrations } & \multirow[b]{2}{*}{$P$ value } & \multirow[b]{2}{*}{$\mathrm{P}<0.05$} \\
\hline & $\begin{array}{l}{ }^{*} \text { Treated cells } \\
\mathrm{pg} / \mathrm{ml}\end{array}$ & $\begin{array}{l}{ }^{*} \text { Negative } \\
\text { control } \\
\mathrm{pg} / \mathrm{ml}\end{array}$ & & \\
\hline 100 & $90.6 \pm 11.64$ & $76.26 \pm 12.3$ & 0.41 & Non-significant \\
\hline 50 & $88.47 \pm 14.6$ & & 0.53 & \\
\hline 25 & $86.42 \pm 8.47$ & & 0.5 & \\
\hline 12.5 & $86.11 \pm 9.33$ & & 0.53 & \\
\hline 6.25 & $84.75 \pm 10.18$ & & 0.6 & \\
\hline 3.12 & $83.63 \pm 12.85$ & & 0.68 & \\
\hline
\end{tabular}

Note: *All the results are shown as mean $\pm 2 \mathrm{SE}$.

IL-2 level of each extract concentration was compared with that of the negative control (PBMC without extract). level in PBMC treated with MBS extract was high in cells treated with high concentrations of the extract; on the other hand, the level of IFN- $\gamma$ decreased in dose dependent manner with decreasing concentrations of MBS extract indicating a stimulatory effect of MBS extract on the synthesis of IFN- $\gamma$ by PBMC (Table 4). Moreover, the results indicated the dose dependent nature of IFN- $\gamma$ synthesis by PBMC in response to MBS extract treatment.

On the other hand, the level of Th2 cytokine, IL-4, in culture supernatants of PBMC treated with MBS extract was much lower than in untreated cells $(\mathrm{P}<0.05)$. These findings demonstrated a significant decrease of IL-4

Table 4 The level of IFN- $\gamma$ produced by PBMC after treatment with different concentrations of MBS extract

\begin{tabular}{lllll}
\hline $\begin{array}{l}\text { Extract } \\
\text { concentrations } \\
\mathbf{m g} / \mathbf{m l}\end{array}$ & $\begin{array}{l}\text { IFN- } \mathbf{p} \text { concentrations } \\
\text { cells } \mathbf{~ p g} / \mathbf{m l}\end{array}$ & $\begin{array}{l}\text { *Negative } \\
\text { control } \\
\mathbf{p g} / \mathbf{m l}\end{array}$ & & \\
\hline 100 & $288.63 \pm 13.65$ & $84.38 \pm 11.5$ & $<0.0001$ & Significant \\
50 & $238.57 \pm 20.5$ & $<0.0001$ & Significant \\
25 & $204.62 \pm 12.64$ & $<0.0001$ & Non-significant \\
12.5 & $133.85 \pm 10.53$ & 0.006 & Non-significant \\
6.25 & $102.49 \pm 9.69$ & 0.24 & Non-significant \\
3.12 & $87.92 \pm 11.22$ & 0.83 & Non-significant \\
\hline
\end{tabular}

Note: *All the results are shown as mean \pm 2 SE.

IFN- $\gamma$ level of each extract concentration was compared with that of the negative control (PBMC without extract). 
level, in dose dependent manner, with increasing concentrations of MBS extracts used in the treatment of PMBC. This reflects clearly an inhibitory effect of MBS extract on the production of IL-4 cytokine (Table 5).

\section{Specific immune response by human cancer cells}

The human cancer cell lines were treated with MBS extract concentrations less than the IC50 for each extract. These concentrations allowed the detection of the anticancer cytokines production in the culture supernatants of HeLa and HepG2 cells (Figure 4). The IFN- $\beta$ levels in culture supernatants of HeLa and HepG2 treated with MBS extract showed significant and dose-dependent increase $(\mathrm{P}<0.05)$ when compared to that of untreated cells (Tables 6 and 7). Accordingly, MBS extract revealed a clear stimulatory effect on the synthesis of IFN- $\beta$ by both HeLa and HepG2 cells. Similarly, TNF- $\alpha$ levels showed a remarkable increase in the culture supernatants of HeLa and HepG2 cells treated with MBS extract when compared to that of untreated cells. Clearly, the MBS-driven increase of TNF- $\alpha$ levels was also in a dose dependent manner (Tables 8 and 9).

\section{MBS extract induced apoptosis and cell cycle arrest in human cancer cells}

The flow cytometric analysis showed possibility of MBS extract to induce apoptosis in the treated cells in comparison to untreated cells (Figures 5 and 6). By testing the apoptosis for fixed time interval, $24 \mathrm{~h}$, and by using different doses of MBS extract, the percentage of the apoptotic cells were directly correlated with the concentration of MBS extract. MBS extract induced apoptosis, in a dose dependent manner, in treated HeLa and HepG2 cells while no observed apoptosis was found in untreated cells $(\mathrm{P}<0.05)$. The IC50 of MBS extract induced apoptosis in 56.6 and $55.4 \%$ of HeLa and HepG2 cells, respectively, after 24 h of treatment (Figure 7).

Table 5 The level of IL-4 produced by PBMC after treatment with different concentrations of MBS extract

\begin{tabular}{lllll}
\hline $\begin{array}{l}\text { Extract } \\
\text { concentrations } \\
\mathbf{m g} / \mathbf{m l}\end{array}$ & \begin{tabular}{l} 
IL-4 concentrations \\
\cline { 2 - 3 } cells $\mathbf{~ p g} / \mathbf{m l}$
\end{tabular} & $\begin{array}{l}{ }^{*} \text { Negative } \\
\text { control } \\
\mathbf{p g} / \mathbf{m l}\end{array}$ & $\mathbf{P}$ value & $\mathbf{P}<\mathbf{0 . 0 5}$ \\
\hline 100 & $21.63 \pm 6.8$ & $71.52 \pm 9.94$ & 0.001 & Significant \\
50 & $37.5 \pm 7.11$ & & 0.015 & Significant \\
25 & $41.86 \pm 10.4$ & 0.022 & Significant \\
12.5 & $58.9 \pm 9.48$ & 0.37 & Non-significant \\
6.25 & $62.6 \pm 12.56$ & 0.62 & Non-significant \\
3.12 & $68.19 \pm 7.2$ & 0.9 & Non-significant \\
\hline
\end{tabular}

Note: *All the results are shown as mean \pm 2 SE.

IL-4 level of each extract concentration was compared with that of the negative control (PBMC without extract).
By testing apoptosis at different time intervals, the flow cytometric analysis of HeLa and HepG2 cells treated with the IC50 of MBS extract showed that the extract provoked significant apoptosis $(\mathrm{P}<0.05)$ in the treated HeLa and HepG2 cells in a time dependent manner when compared with untreated cells (Figure 8). There were no significant differences $(\mathrm{P}>0.05)$ in the percentage of HeLa and HepG2 cells in different cell cycle phases when treated with MBS IC50 for different times (Figures 9A and 10A). However, MBS IC50 induced cell cycle arrest in G0/G1 phase in the treated HeLa, but not HepG2 when compared to untreated cells. The mean percentage of HeLa cells, treated with MBS extract for different times, in G0/G1 phase was higher than that in untreated cells (Figure 9B). The treatment with MBS IC50 increased the percentage of $\mathrm{HeLa}$ cells in G0/G1 phase from $62.87 \pm 2.1 \%$, in untreated cells, to $80.48 \pm 2.97 \%$. Alternatively, MBS IC50 did not increase significantly the percentage of HepG2 cells in G0/G1 phase from 60.83 \pm 3.6 , in untreated cells, to $65.30 \pm 3.25 \%$ (Figure 10B).

\section{The apoptosis- and cell cycle- related genes in human cancer cells treated with MBS extract}

The results disclosed that 12,16 , and $20 \mathrm{~h}$ were the best times to study the expression level of the apoptosis- and cell cycle- related genes using real-time quantitative PCR. The other treatments of $8,24,48$, and $72 \mathrm{~h}$ were ignored because they either gave very low or very high percentage of apoptotic cells. Studying the apoptosisand cell cycle- related genes cannot be covered well during very early phase of extracts' treatment during which not all apoptosis genes might be upregulated or downregulated; alike, during very late phase of apoptosis, most cells already died which renders measuring the expression of selected genes erroneous. A single peak at the expected melting temperature of PCR product, melting temperature $(\mathrm{Tm}) 76-87^{\circ} \mathrm{C}$, was observed while no significant premature peaks were found indicating that primer dimers were minimal and providing further evidence on the specific detection of the target mRNA genes (Figure 11). The PCR efficiency of the primers used was greater than $90 \%$ and the correlation coefficients were greater than 0.99 .

MBS IC50 showed remarkable influence on the expression of the apoptosis-related genes in a positive and negative manner on both HeLa and HepG2 cells (Figures 12 and 13). MBS IC50 upregulated Bax gene expression in HeLa and HepG2 cells after 12, 16, and $20 \mathrm{~h}(\mathrm{P}<0.05)$. Bax upregulation at $16 \mathrm{~h}$ was not significantly different from that at 12 and $20 \mathrm{~h}(\mathrm{P}>0.05)$. Incubating HeLa and HepG2 cells with MBS IC50 did not show any effect on Bcl-2 gene expression after all the tested times of incubation $(\mathrm{P}>0.05)$. MBS IC50 upregulated Caspase 7 gene expression after 12, 16, and $20 \mathrm{~h}$ of treatment of 

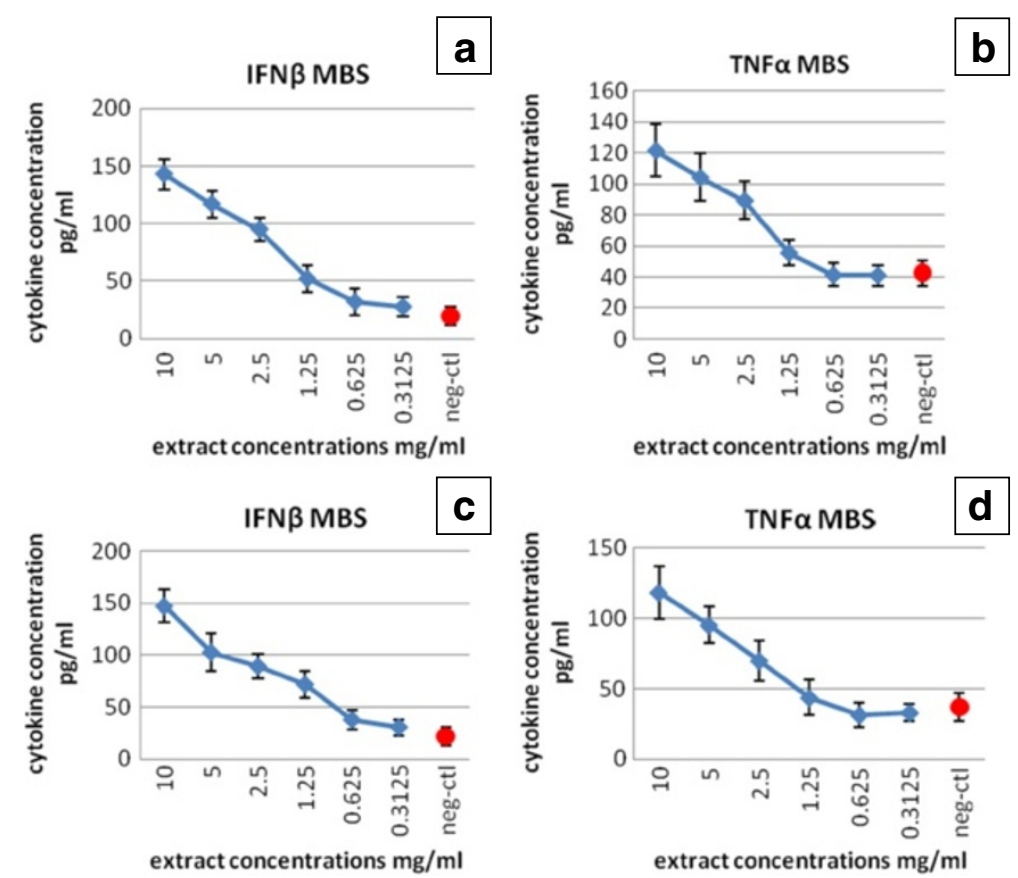

Figure 4 Figures demonstrate the level of the produced cytokines, in comparison with negative control (neg-ctl), in culture supernatant of HeLa cell ( $\mathbf{a}$ and $\mathbf{b})$ and HepG2 cells ( $\mathbf{c}$ and d) after treatment with MBS extract.

HeLa cells $(\mathrm{P}<0.05)$. Alternatively, MBS IC50 upregulated Caspase 7 gene in the treated HepG2 cells only after $16 \mathrm{~h}$ $(\mathrm{P}<0.05)$ with no significant difference from $12 \mathrm{~h}$ upregulation $(\mathrm{P}>0.05)$. The expression of Caspase 8 gene in the treated HeLa cells was upregulated after 12, 16, and $20 \mathrm{~h}$ of treatment $(\mathrm{P}<0.05)$ with no significant differences among the expressions of all of them $(P>0.05)$. At the same time, MBS IC50 upregulated Caspase 8 and 9 genes' expressions in HepG2 cells only after 16h ( $\mathrm{P}<$ $0.05)$ with no significant differences in their expressions from $12 \mathrm{~h}$ treatment $(\mathrm{P}>0.05)$. On the contrary, MBS

Table 6 The level of IFN- $\beta$ produced by cancer cells, HeLa, after treatment with different concentrations of MBS extract

\begin{tabular}{lllll}
\hline $\begin{array}{l}\text { Extract } \\
\text { concentrations } \\
\mathbf{m g} / \mathbf{m l}\end{array}$ & $\begin{array}{l}\text { IFN- } \boldsymbol{\beta} \text { concentrations } \\
\text { *Treated } \\
\text { cells } \mathbf{~ p g} / \mathbf{m l}\end{array}$ & $\begin{array}{l}{ }^{*} \text { Negative } \\
\text { control } \\
\mathbf{p g} / \mathbf{m l}\end{array}$ & $\mathbf{P}$ value & $\mathbf{P}<\mathbf{0 . 0 5}$ \\
\hline 10 & $142.85 \pm 13.18$ & $19.54 \pm 8.23$ & $<0.0001$ & Significant \\
5 & $116.83 \pm 11.52$ & & $<0.0001$ & Significant \\
2.5 & $94.8 \pm 10.32$ & $<0.0001$ & Significant \\
1.25 & $51.67 \pm 11.47$ & 0.04 & Significant \\
0.625 & $31.67 \pm 11.3$ & 0.4 & Non-significant \\
0.31 & $27.31 \pm 8.47$ & 0.73 & Non-significant \\
\hline
\end{tabular}

Note: *All the results are shown as mean \pm 2 SE.

IFN- $\beta$ level of each extract concentration was compared with that of the negative control (HeLa without extract).
IC50 upregulated Caspase 9 gene expression in the treated HeLa cells after $12 \mathrm{~h}(\mathrm{P}<0.05)$ with significant differences $(\mathrm{P}<0.05)$ from that after 16 and $20 \mathrm{~h}$ treatments.

The ratio of $\mathrm{Bax}$ to $\mathrm{Bcl}-2$ proteins influences the apoptotic rate of cells; therefore, $\mathrm{Bax} / \mathrm{Bcl}-2$ ratio was calculated in treated and untreated HeLa and HepG2 cells (Table 10). The ratio of $\mathrm{Bax} / \mathrm{Bcl}-2$ in the treated HeLa and HepG2 cells after 12, 16, and 20h with MBS IC50 was higher than in the untreated cells $(\mathrm{P}<0.05)$.

Because flow cytometric analysis showed cell cycle arrest by MBS extracts at G0/G1 phase, the regulatory

Table 7 The level of IFN- $\beta$ produced by cancer cells, HepG2, after treatment with different concentrations of MBS extract

\begin{tabular}{lllll}
\hline $\begin{array}{l}\text { Extract } \\
\text { concentrations } \\
\mathbf{m g} / \mathbf{m l}\end{array}$ & $\begin{array}{l}{ }^{*} \text { IFN- } \boldsymbol{\beta} \text { concentrations } \\
\text { cells } \mathbf{~ p g} / \mathbf{m l}\end{array}$ & $\begin{array}{l}{ }^{*} \text { Negative } \\
\text { control } \\
\mathbf{p g} / \mathbf{m l}\end{array}$ & $\mathbf{P}$ value & $\mathbf{P}<\mathbf{0 . 0 5}$ \\
\hline 10 & $147.38 \pm 16.38$ & $21.56 \pm 8.48$ & $<0.0001$ & Significant \\
5 & $102.67 \pm 18.43$ & & 0.002 & Significant \\
2.5 & $89.21 \pm 11.42$ & 0.0001 & Significant \\
1.25 & $71.68 \pm 12.73$ & & 0.006 & Significant \\
0.625 & $37.5 \pm 9.58$ & & 0.23 & Non-significant \\
0.31 & $30.17 \pm 7.34$ & & 0.6 & Non-significant \\
\hline
\end{tabular}

Note: *All the results are shown as mean \pm 2 SE.

IFN- $\beta$ level of each extract concentration was compared with that of the negative control (HepG2 without extract). 
Table 8 The level of TNF-a produced by cancer cells, HeLa, after treatment with different concentrations of MBS extract

\begin{tabular}{lllll}
\hline $\begin{array}{l}\text { Extract } \\
\text { concentrations } \\
\mathbf{m g} / \mathbf{m l}\end{array}$ & $\begin{array}{l}{ }^{*} \text { Treated } \\
\text { cells } \mathbf{~ p g} / \mathbf{m l}\end{array}$ & $\begin{array}{l}{ }^{*} \text { Negative } \\
\mathbf{c o n t r o l} \\
\mathbf{p g} / \mathbf{m l}\end{array}$ & $\mathbf{P}$ value & $\mathbf{P}<\mathbf{0 . 0 5}$ \\
\hline 10 & $121.72 \pm 16.83$ & $42.74 \pm 8.26$ & 0.001 & \\
5 & $104.36 \pm 15.28$ & Significant \\
2.5 & $89.42 \pm 12.16$ & 0.004 & Significant \\
1.25 & $55.69 \pm 8.28$ & 0.007 & Significant \\
0.625 & $41.3 \pm 7.39$ & 0.28 & Non-significant \\
0.31 & $41.13 \pm 6.71$ & 0.89 & Non-significant \\
\cline { 1 - 2 } & & 0.87 & Non-significant \\
\hline
\end{tabular}

Note: *All the results are shown as mean $\pm 2 \mathrm{SE}$.

TNF-a level of each extract concentration was compared with that of the negative control (HeLa without extract).

proteins of G0/G1 phase in the mammalian cell cycle, cyclin D, E, and A were studied. These cyclins are responsible for the activation of cyclin-dependent kinases (cdk) in G1 and S phases of the cell cycle of HeLa and HepG2 cells. Moreover, the mRNA expression of the proteins responsible for the inhibition of cyclin-cdk active complexes of the G1 and S phases of HeLa and HepG2 cells exposed to the IC50 of MBS extracts were studied as well, namely tumor suppressor proteins p27, p21, and p53 (Figure 4.24 and Figure 4.25).

The current findings of real-time quantitative PCR were congruous with that of flow cytometry. In addition, the results of real time PCR granted valuable details on some aspects and mechanisms that underlie the cell cycle arrest ability of MBS extract. For MBS extract effect on HeLa cells, it was found that the expression of both cyclin D and E, cyclins of G0/G1 phase, was downregulated after 12, 16, and 20h exposure of HeLa cells to MBS extract

Table 9 The level of TNF- $a$ produced by cancer cells, HepG2, after treatment with different concentrations of MBS extract

\begin{tabular}{|c|c|c|c|c|}
\hline \multirow[b]{2}{*}{$\begin{array}{l}\text { Extract } \\
\text { concentrations } \\
\mathrm{mg} / \mathrm{ml}\end{array}$} & \multicolumn{2}{|c|}{ TNF- $a$ concentrations } & \multirow[b]{2}{*}{$P$ value } & \multirow[b]{2}{*}{$\mathrm{P}<0.05$} \\
\hline & $\begin{array}{l}{ }^{*} \text { Treated } \\
\text { cells } \mathrm{pg} / \mathrm{ml}\end{array}$ & $\begin{array}{l}{ }^{*} \text { Negative } \\
\text { control } \\
\mathrm{pg} / \mathrm{ml}\end{array}$ & & \\
\hline 10 & $118.47 \pm 18.3$ & $37.21 \pm 9.98$ & 0.002 & Significant \\
\hline 5 & $95.28 \pm 12.89$ & & 0.003 & Significant \\
\hline 2.5 & $70.14 \pm 14.22$ & & 0.08 & Non-significant \\
\hline 1.25 & $43.85 \pm 12.63$ & & 0.68 & Non-significant \\
\hline 0.625 & $31.56 \pm 8.91$ & & 0.67 & Non-significant \\
\hline 0.31 & $33.16 \pm 6.38$ & & 0.74 & Non-significant \\
\hline
\end{tabular}

Note: *All the results are shown as mean \pm 2 SE.

TNF-a level of each extract concentration was compared with that of the negative control (HepG2 without extract). with no significant differences $(\mathrm{P}>0.05)$ while the expression of cyclin A, cyclin of late G1 and S phase, was not affected by MBS extract ( $\mathrm{P}>0.05)$. However, the cdkinhibitory protein, p27 was significantly upregulated after $16 \mathrm{~h}(\mathrm{P}<0.05)$ while its upregulation after 12 and $20 \mathrm{~h}$ was not significant $(\mathrm{P}>0.05)$ indicating that $\mathrm{p} 27$ peak of upregulation was around 16h. For p21 and p53, both of them were largely upregulated, especially p21, after 12 and $16 \mathrm{~h}$ $(\mathrm{P}<0.05)$ but not after $20 \mathrm{~h}(\mathrm{P}>0.05)$. The upregulation of p21 reached 128 folds of expression after $12 \mathrm{~h}$ and above 512 folds of expression after $16 \mathrm{~h}$ while the upregulation of p53 reached 16 folds after $12 \mathrm{~h}$ and more than 32 after $16 \mathrm{~h}$. Both p53 and p21 are expressed together for the inhibition of cyclin-cdk complexes and peaked after $16 \mathrm{~h}$ of cells exposure to MBS extract indicating a clear inhibiting role of MBS extract for the cell cycle at G0/G1 through cdk-inhibitory proteins rather than affecting much the expression level of cyclins themselves.

The effect of MBS extract on HepG2 cells was somehow different from its effect on HeLa cells. MBS extract did not show, via both flow cytometry and real time $\mathrm{PCR}$, a remarkable inhibitory effect on the cell cycle of HepG2 cells. The mRNA expression level of cyclin D and A was not affected by MBS extract $(\mathrm{P}>0.05)$ while cyclin $\mathrm{E}$ was upregulated after $12 \mathrm{~h}(\mathrm{P}<0.05)$. Moreover, the expression of $\mathrm{p} 27$ and $\mathrm{p} 21$ proteins did not reach the significant level of upregulation $(P>0.05)$ indicating that MBS extract has little inhibitory effect on the cell cycle of HepG2 cells. Nevertheless, p53 was the only protein shown to be significantly upregulated after 12 and $20 \mathrm{~h}$ $(\mathrm{P}<0.05)$ and borderline upregulation $(\mathrm{P}=0.048)$ after 16h. However, it is not well understood why p53 was upregulated while other tumor suppressor proteins were not. Collectively, the current results of the effect of MBS extract on HepG2 are in harmony with flow cytometry results. Both assays revealed weak inhibitory effect of MBS extract on HepG2, but not HeLa, cells indicating a cell-specific activity of MBS extract on the cell cycle of different types of cells. The sole upregulation of p53 by MBS extract explains some aspects of the remarkable apoptotic activity of MBS extract towards HepG2 cells.

\section{Discussion}

The cytotoxic effects of MBS extract was investigated on two of the most important types of cancer in Asian countries. Depending on recent studies, hepatocellular carcinoma, a liver cancer, is considered to be one of the most common cancers worldwide with an extremely poor prognosis. Moreover, it ranks as the second leading cause of cancer-related deaths in China and many Asian regions [29]. On the other hand, cervical cancer continues to be the commonest cause of death among women in developing countries. In addition, it is the second most frequent cancer among females worldwide [30]. 
(a)
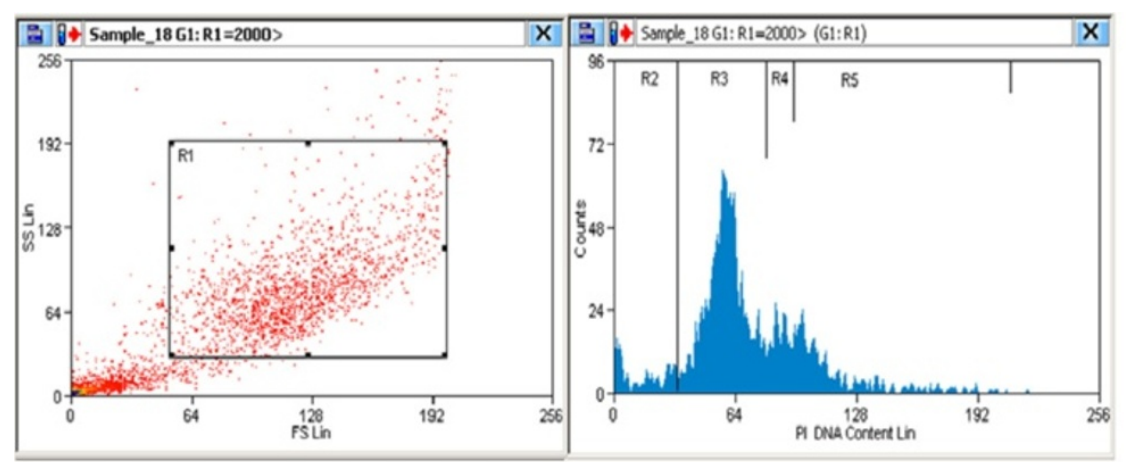

(b)
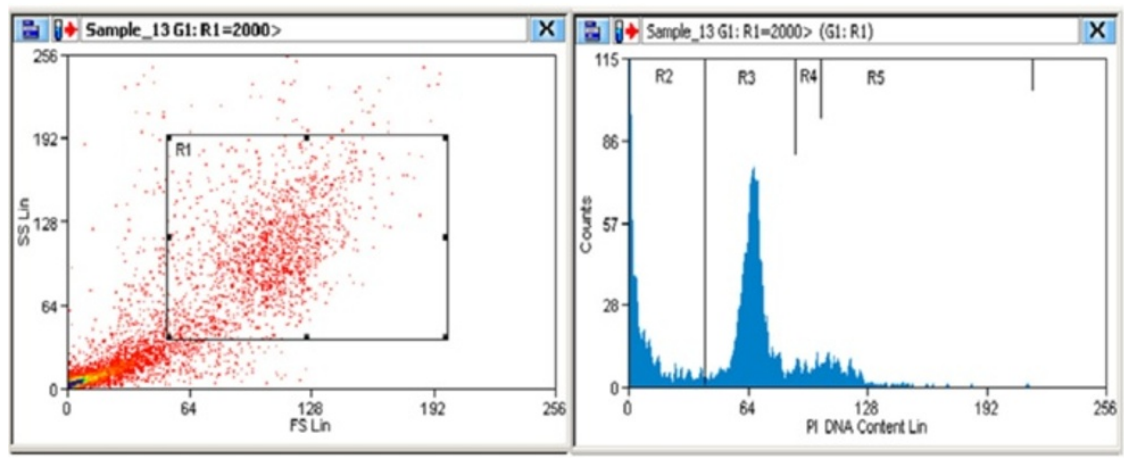

(c)
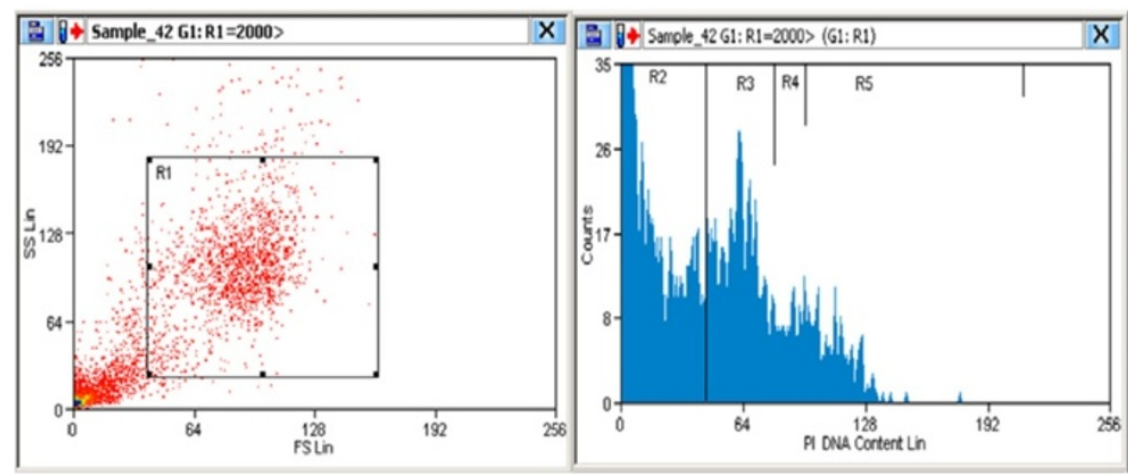

(d)
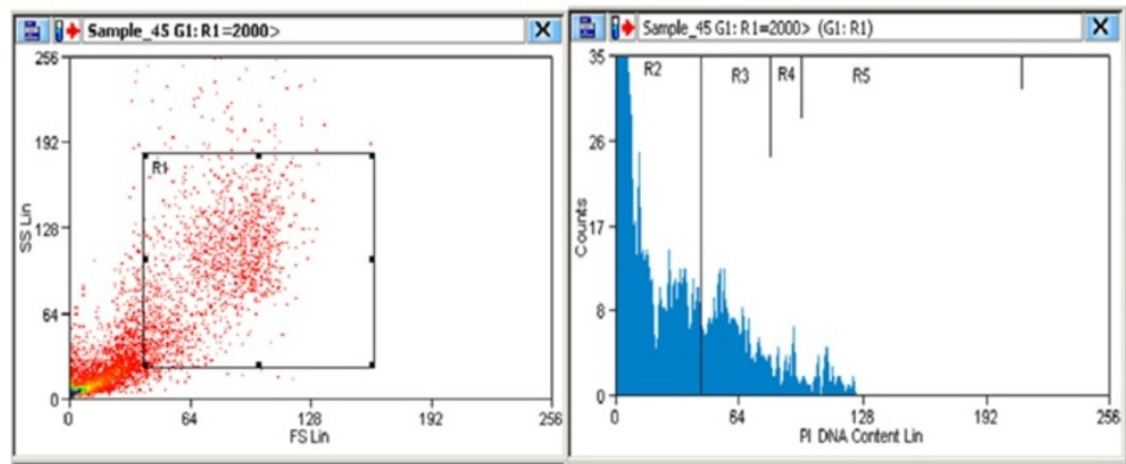

Figure 5 DNA content frequency histograms representing HeLa cells after $24 \mathrm{~h}$ from (a) untreated cultures (b) cultures treated with MBS extract concentration $<$ IC50 (c) cultures treated with MBS extract IC50 (d) cultures treated with MBS extract concentration >IC50. The treatment affected the cell cycle distribution and induce apoptosis. The cells were stained with PI. Fluorescence of the Pl-stained cells was measured using CyAn ADP appartus and Summit (V4.3) software. The software program provides the estimate of percentage of cells with fractional DNA content (apoptotic cells: R2) and cells in G0/G1 (R3), S (R4), and G2/M (R5) phases of the cycle. Total cell number (R1). 
(a)
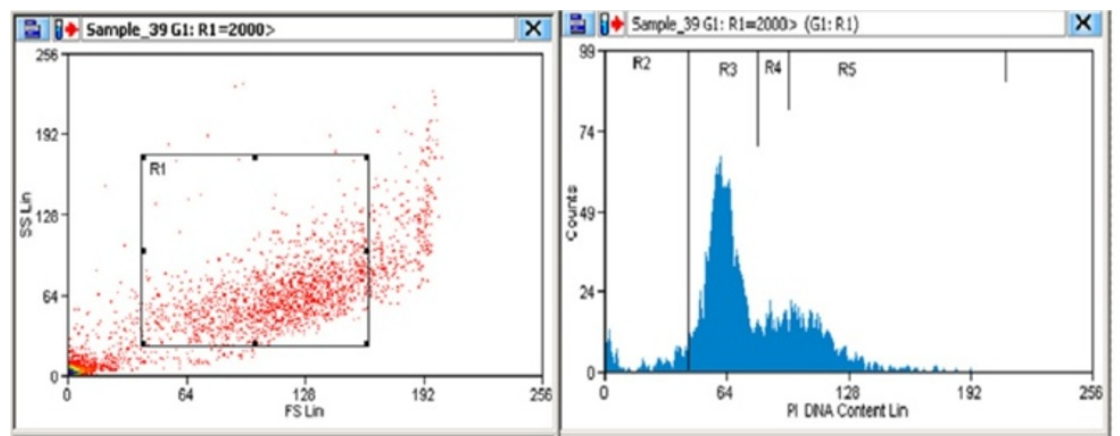

(b)
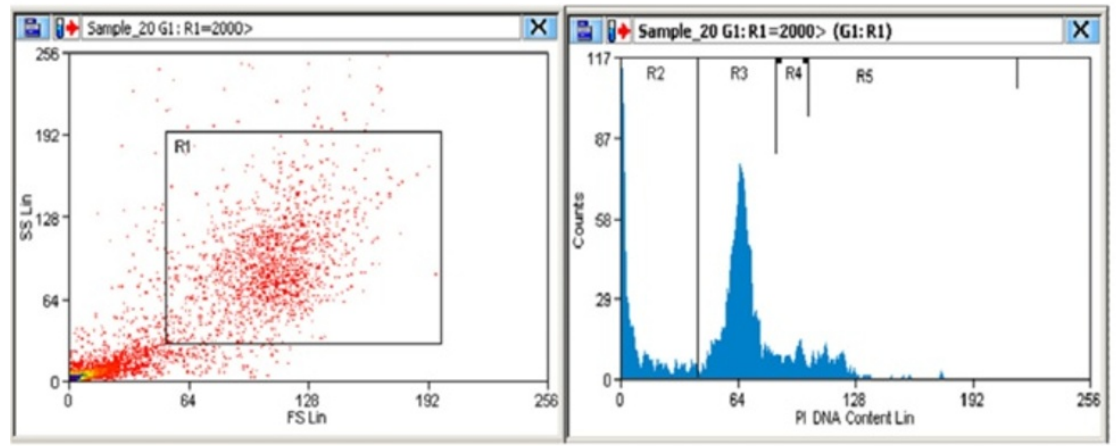

(c)
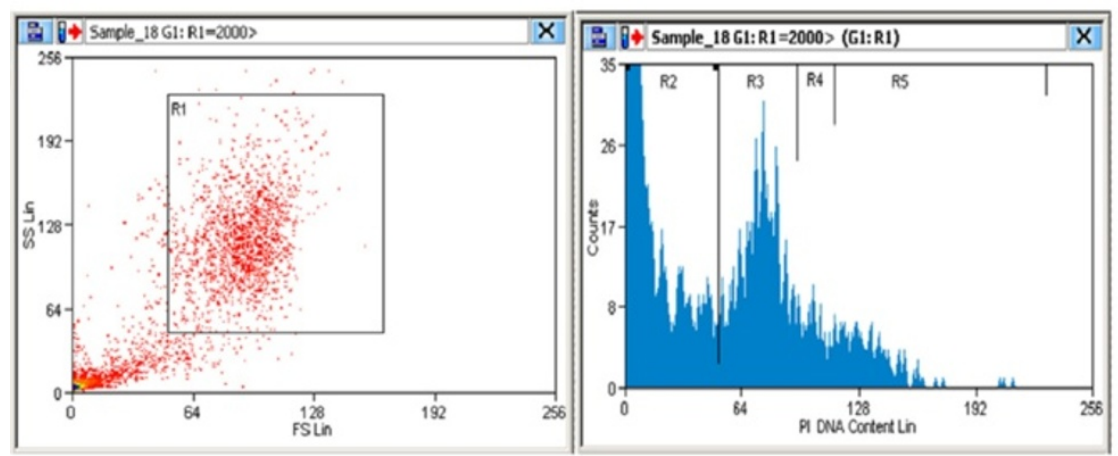

(d)
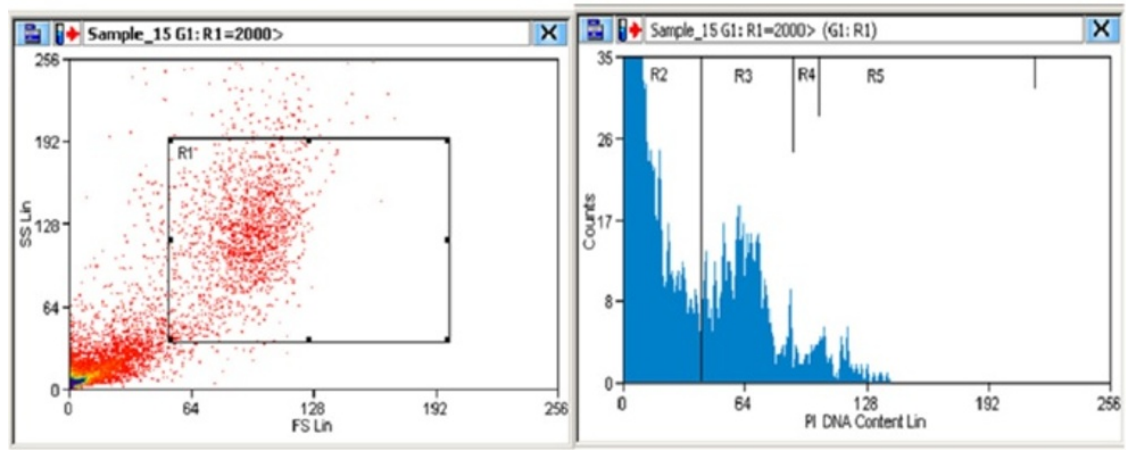

Figure 6 DNA content frequency histograms representing HepG2 cells after $24 \mathrm{~h}$ from (a) untreated cultures (b) cultures treated with MBS extract concentration $<$ IC50 (c) cultures treated with MBS extract IC50 (d) cultures treated with MBS extract concentration $>$ IC50. The treatment affected the cell cycle distribution and induce apoptosis. The cells were stained with PI. Fluorescence of the Pl-stained cells was measured using CyAn ADP appartus and Summit (V4.3) software. The software program provide the estimate of percentage of cells with fractional DNA content (apoptotic cells: R2) and cells in G0/G1 (R3), S (R4), and G2/M (R5) phases of the cycle. Total cell number (R1). 

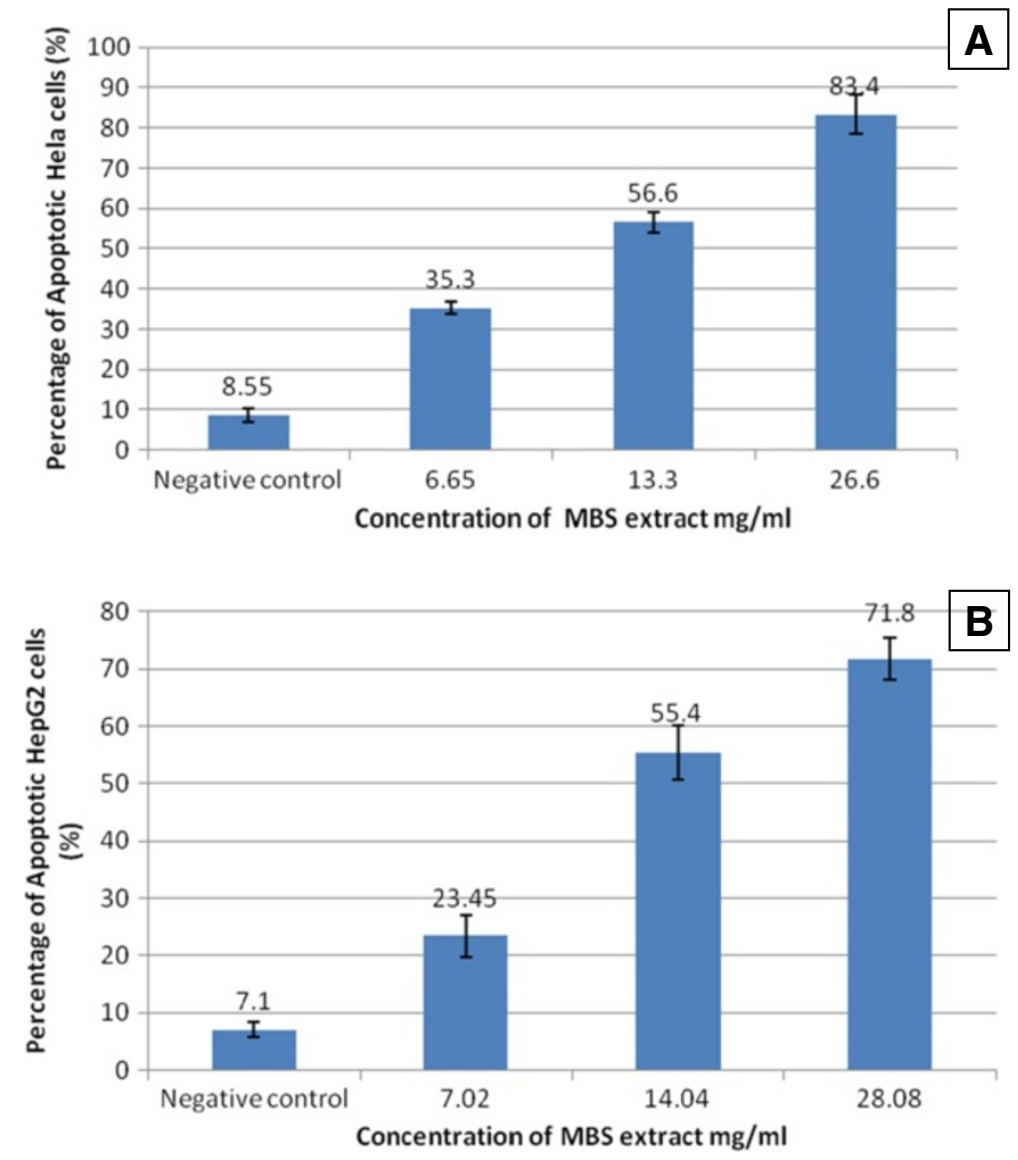

Figure 7 A graph of flow cytometric analysis shows the percentage of apoptotic cells after treatment with MBS extract for $24 \mathrm{~h}$ in comparison with untreated cells (Negative control). The extract's concentrations represent 2-fold serial dilutions (concentration $>$ IC50 > concentration). A) Apoptotic \% of HeLa cells. B) Apoptotic \% HepG2 cells. The increase in the percentage of the apoptotic cells was dose dependent.

The findings of the current study revealed effective cytotoxic effects on HeLa and HepG2 cells by MBS extract. No previous studies have investigated the cytotoxic effect of MBS extract. Interestingly, in the current study, MBS extract showed selective cytotoxic effects against both HeLa and HepG2 cells with SI values of 12.44 and 11.94, respectively. Taken into account the SI biological efficacy, or SI, $\geq 10$ is considered not due to non-specific cytotoxicity, the SI values of MBS extract reflect remarkable selectivity. There is a need to find new chemical agents able to differentiate between normal and cancerous cells. This is a necessary criterion to selectively kill cancer cells and this such selective natural proidcts have become highly needed [31]. It has been proven that germination of the mung bean causes a rise in the total content of the antioxidant components like phenolic compounds, $\alpha$-tocopherol and vitamin $C$ [32]. The absence of significant differences in MBS cytotoxic effects on HeLa and HepG2 cells may highlight the common cytotoxic mechanisms that are possibly used by the extract to seize the cell growth of both cell lines. One of the possible mechanisms responsible for the cytotoxic effect of MBS extract is the great possibility of flavonoids and phenolics in reducing alkylperoxyl radical (ROO•) content which has a role in radical-mediated pathogenesis such as carcinogenesis. It was found that the scavengers of alkylperoxyl radical (ROO•) may play an important role in cancer prevention [33]. Another possible mechanism that may explain the results of this study is the synergistic effect of phenolic compounds and $\alpha$-tocopherol. It was observed that phenolic compounds indirectly increase the (ROO•)-scavenging capacity in vivo by increasing the level of $\alpha$-tocopherol [33]. It is known that $\alpha$-tocopherol, one of vitamin $E$ family members, has a potent antioxidant activity [34]. In addition, many studies proved the efficacy of $\alpha$-tocopherol as antithrombotic, anticoagulant, neuroprotective, antiproliferative, immunomodulatory, cell membranestabilizing, and antiviral [35-38]. Thus, the clear cytotoxic effect of MBS extract may be related to the efficacy 

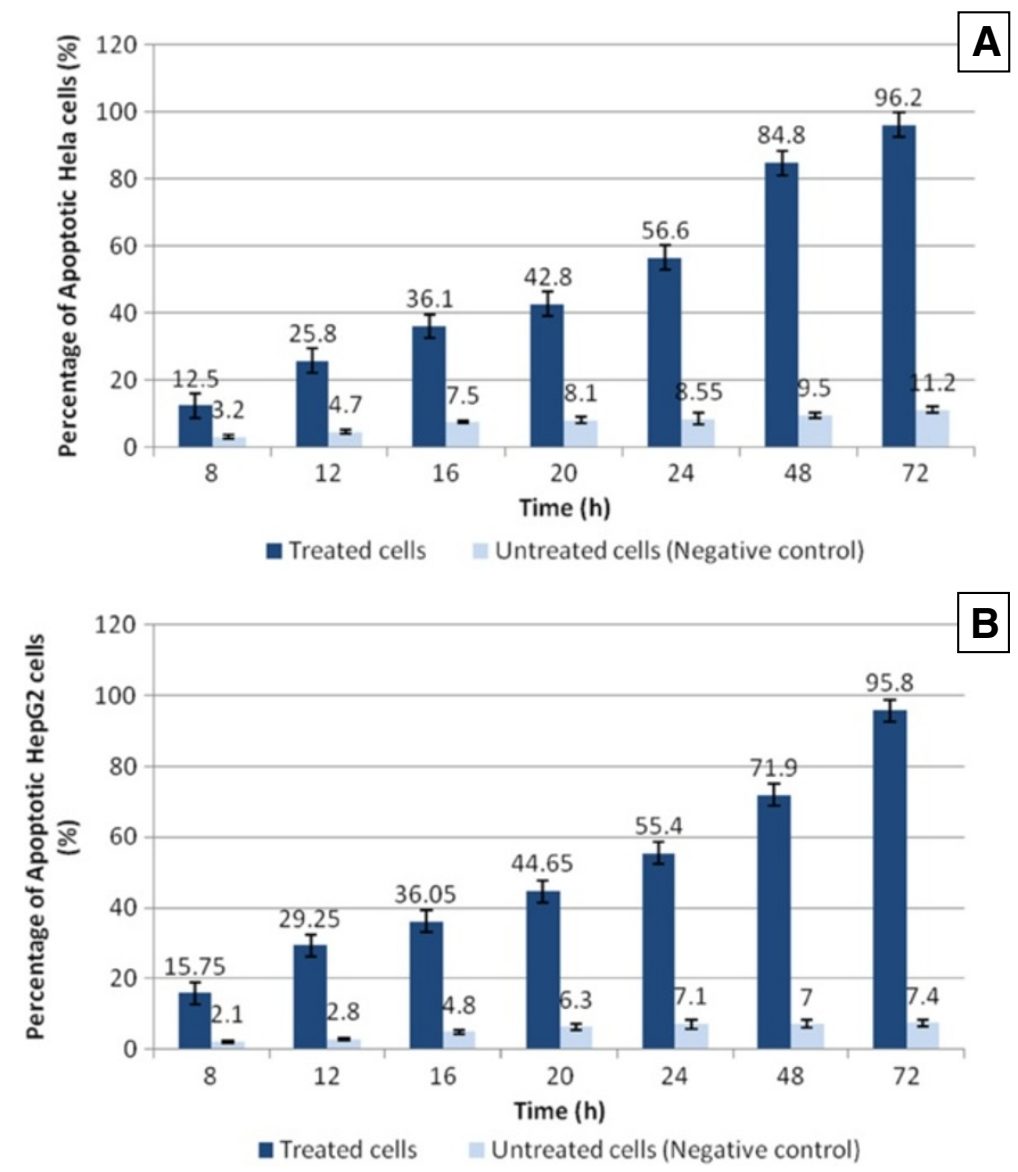

Figure $8 \mathrm{~A}$ graph of flow cytometric analysis showes the percentage of apoptotic cells after treatment with MBS extract comparison with untreated cells. The percentage of apoptotic cells increased with the time of treatment by extract IC50. A) Apoptotic \% of HeLa cells. B) Apoptotic \% of HepG2 cells. The increase in the percentage of the apoptotic cells was time dependent.

of $\alpha$-tocopherol alone [39] or, more likely, together with phenolic compounds. Besides, the presence of anticarcinogenic substances, such as vitamin $C$, [40] in the germinated mung bean sprouts may enhance the cytotoxic effect of MBS extract.

MBS extract was shown to be a good inducer for both anticancer cytokines, i.e., TNF- $\alpha$ and IFN $-\beta$ in culture supernatants of HeLa and HepG2 cells. There was a significant increase in their levels in MBS-treated cells when compared to untreated cells. The increase was dose dependent which reflected the capability of MBS extract as an inducer to the production of these two essential anticancer cytokines. Both TNF- $\alpha$ and IFN- $\beta$ are important cytokines to regulate cell growth and death [41]. A recent study found that TNF- $\alpha$ and IFN- $\beta$ are major inducible cytokines that function to counteract cellular transformation in a synergistic action [42]. Accordingly, the current study clarified that MBS extract induced the production of TNF- $\alpha$ and IFN- $\beta$ from human cancer cells, and this led to the inhibition of the growth of these cells and this might lead to the death of treated human cancer cells. The cytokines synthesized by cancer cells are released to culture medium and then bind to their receptors on the cell surface of cancer cells, leading to cell growth arrest and apoptosis via an autocrine pathway [22]. The anticancer activity of IFN- $\beta$ has been well recognized [43], whereas TNF- $\alpha$ plays a paradoxical role in carcinogenesis [44]. The ability of MBS extract to induce the production of anticancer cytokines was in agreement with some recent findings. Several studies demonstrated that $\alpha$-tocopherol is considered as a potent antitumor agent which increases apoptosis and decreases proliferation in tumor cells $[45,46]$. Similarly, vitamin C proved to have cytotoxic action on human cancer cells and induce apoptosis [47]. And, it was found that vitamin $\mathrm{C}$ is capable to induce TNF- $\alpha$ production in vivo [48]. Thus, the cytotoxic effect of MBS extract could be partly explained by the induction of anticancer cytokines which in turn induces cell death; moreover, all these actions may be induced by the two important components of MBS extract, i.e., $\alpha$-tocopherol and vitamin C.

Besides inducing anticancer cytokines, there was a need to explore the pro-apoptotoic effect of MBS extract on cancer cells. The flow cytometry analysis was done to 

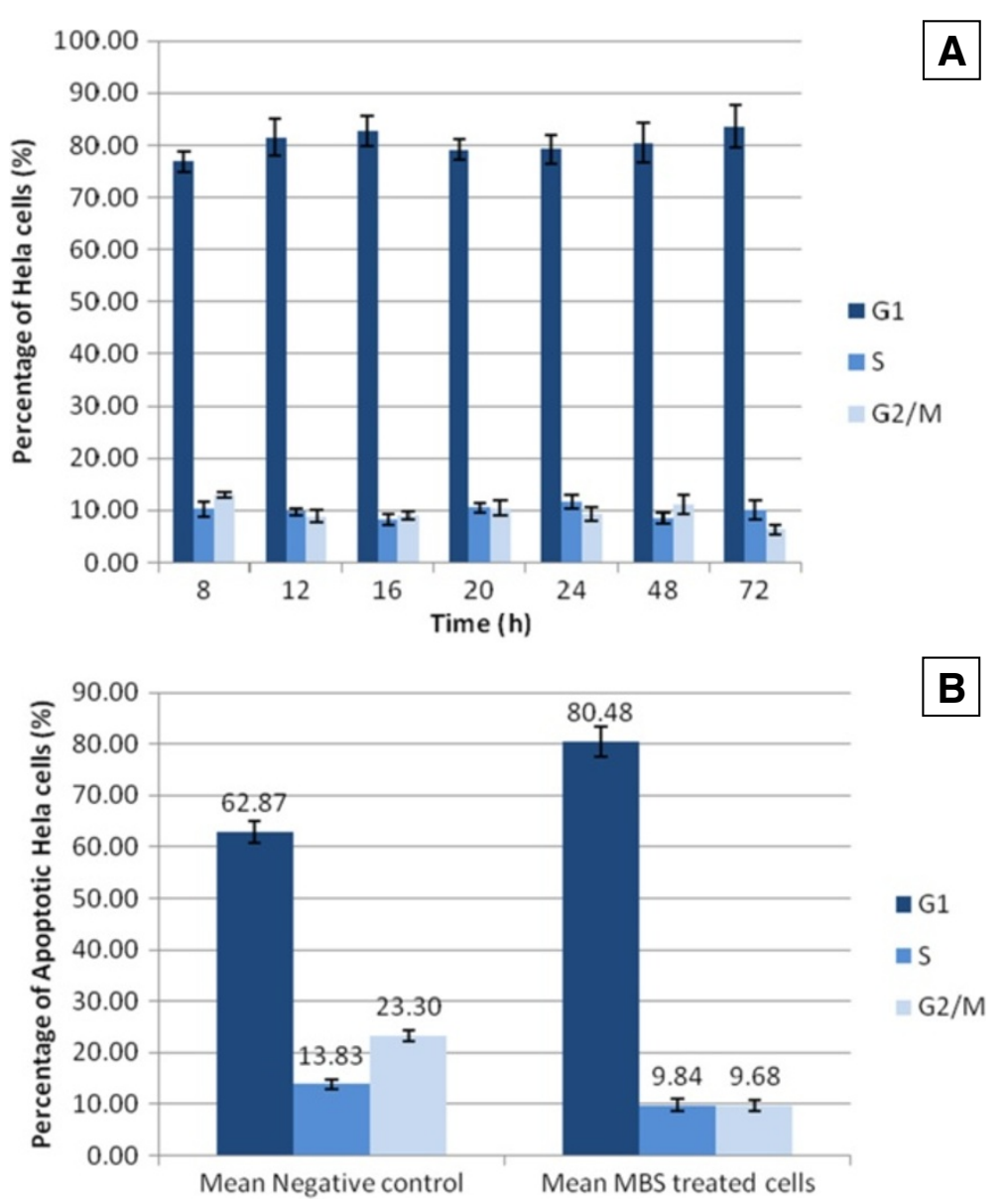

Figure 9 A) Cell cycle arrest of HeLa cells treated by MBS extract IC50 at different time intervals. B) The mean \pm 2 EE of the percentage of cells at G0/G1, S, and G2/M phases of the cell cylce of HeLa cells treated with MBS extract for different times in comparison with that of untreated cells.

investigate the presence or absence of the apoptotic cells in the treated HeLa and HepG2 cells. The results revealed that MBS extract induced apoptosis in the treated cells in a dose and time dependent manner with significant differences from untreated cells. The cell cycle arrest and the induction of apoptosis in cancer cells have become major indicators of anticancer effects [49]. Moreover, the antitumor effects could be attributed to altered biochemical mechanisms, including inhibitions of proliferation, induction of cell cycle arrest at various cell cycle checkpoints, and enhanced apoptosis [50]. The current study revealed that treated HeLa and HepG2 cells with the IC50 of MBS extract induced cell cycle arrest significantly in G0/G1 phase in HeLa but not in HepG2 cells. The mean percentage of HeLa cells, treated with MBS extract for different times, in G0/G1 phase was higher than in untreated cells (Figure 9). The treatment with MBS IC50 increased the percentage of HeLa cells in G0/G1 phase from $62.87 \pm$ $2.1 \%$, in untreated cells, to $80.48 \pm 2.97 \%$. Alternatively, MBS IC50 did not increase significantly the percentage of
HepG2 cells in G0/G1 phase from $60.83 \pm 3.6$, in untreated cells, to $65.30 \pm 3.25 \%$ (Figure 10). The results of this study were in agreement with other previous studies which found that flavonoids, phenolic acids, and other antioxidants inhibit the cancer cell cycle progression, cell proliferation and tumor growth. In addition, they can prevent tumor metastasis by inducing cell-cycle arrest and apoptosis [51,52].

Subsequently, real-time quantitative PCR was used to confirm the deteted aoptotisis by flow cytometry and to detect the underlying mechanism(s) used by MBS extract to induce apoptosis. To demonstrate these mechanism(s), the expression of several apoptosis-related genes was investigated in the current study. Apoptosis is a broad network of signals that act through two major apoptotic pathways: the extrinsic death receptor pathway (via caspase 8), which triggers the activation of a caspase cascade, and the intrinsic mitochondrial pathway (via caspase 9), which shifts the balance in the Bcl-2 family towards the pro-apoptotic members and, consequently, 

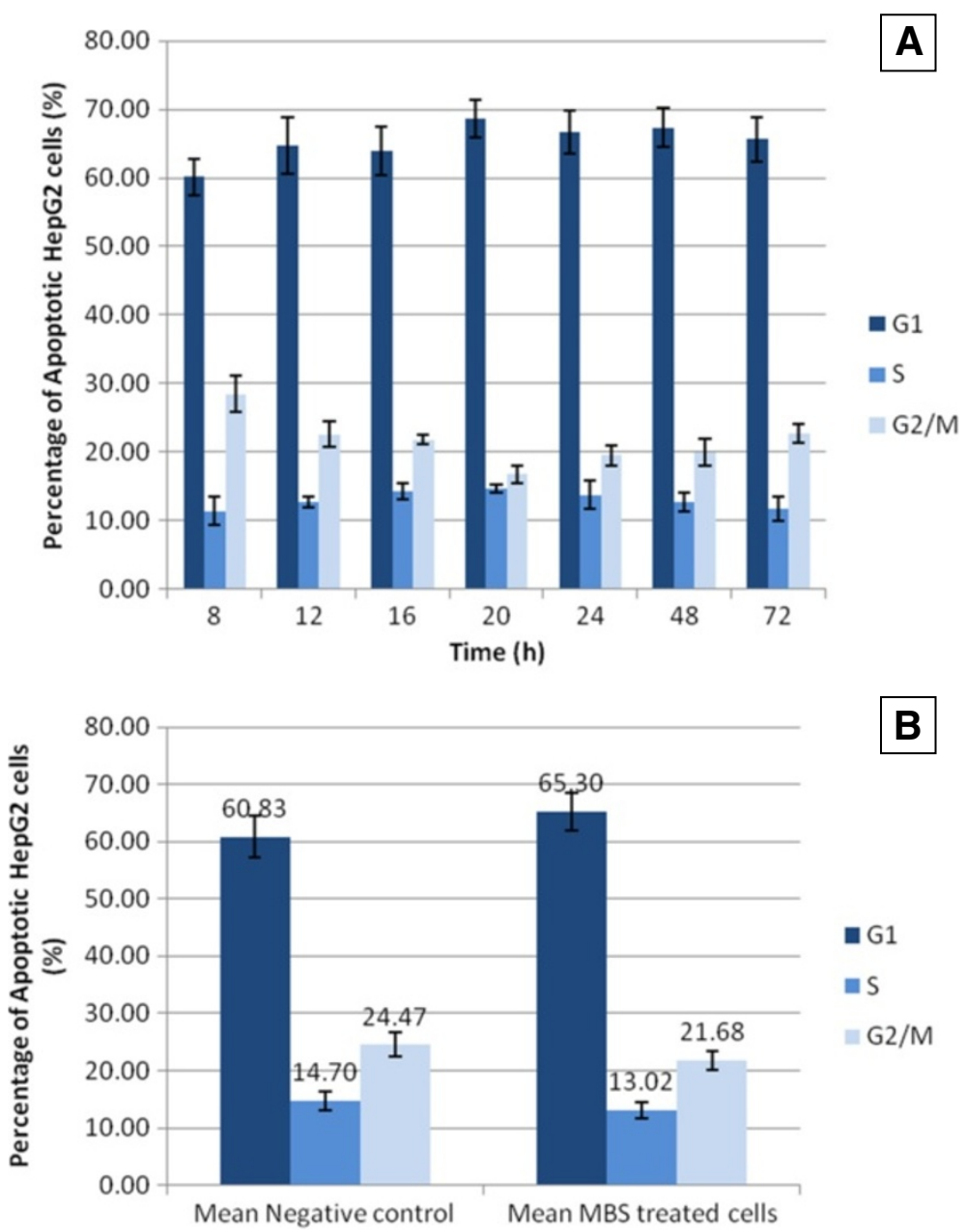

Figure $10 \mathrm{~A}$ ) Cell cycle arrest of HepG2 cells treated by MBS extract IC50 at different time intervals. B) The mean $\pm 2 S E$ of the percentage of cells at G0/G1, S, and G2/M phases of the cell cylce of HepG2 cells treated with MBS extract for different times in comparison with that of untreated cells.

toward caspase-mediated apoptosis [53]. Both caspase 8 and 9 are considered as initiator caspases which in turn can activate the effector caspases, namely caspase 3 and caspase 7, leading to dramatic morphologic changes of apoptosis [54]. In the current study, MBS extract was found to be a potent inducer to the extrinsic pathway of apoptosis via caspase 8 . MBS extract upregulated the gene expression of caspase 8 after $12 \mathrm{~h}$ of treatment in both HeLa and HepG2 cells. Caspase 8 upregulation continued till $20 \mathrm{~h}$ in the treated HeLa cells while it continued maximally till $16 \mathrm{~h}$ in the treated HepG2 cells. It has been shown that the activation of caspase 8 requires the involvement of apoptotic ligands such as TNF- $\alpha$ and Fas ligand [53]. As mentioned earlier, MBS extract stimulated TNF- $\alpha$ production in the culture supernatants of the treated HeLa and HepG2 cells. Thus, we propose that TNF- $\alpha$ which was produced by the treated cells might have an autocrine effect on the same producing cells. And it activated the extrinsic apoptosis pathway via caspase 8 by binding to its receptors on the surface of cancer cells.

The current results revealed that MBS extract upregulated the expression of Bax gene after $12 \mathrm{~h}$ of treatment and this upregulation continued till $20 \mathrm{~h}$. It was stated that cytochrome $c$ release from mitochondria could be controlled by Bax. And the translocation of Bax can alter the outer mitochondrial membrane permeability, leading to cytochrome $c$ release from the mitochondria to the cytosol then activation of the intrinsic apoptosis pathway [55]. Accordingly, MBS extract promoted the intrinsic apoptosis pathway by its ability to upregulate Bax gene. Moreover, the results demonstrated the predominance of Bax gene over Bcl-2 gene in all of the treated cells. It was proven that the ratio of $\mathrm{Bax}$ to $\mathrm{Bcl}-2$ determines, in part, the susceptibility of cells to death signals [28]. For that reason, $\mathrm{Bcl}-2$ proteins have emerged as an attractive target for the development of novel anticancer drugs, and this could be one of the targets hit by MBS active 


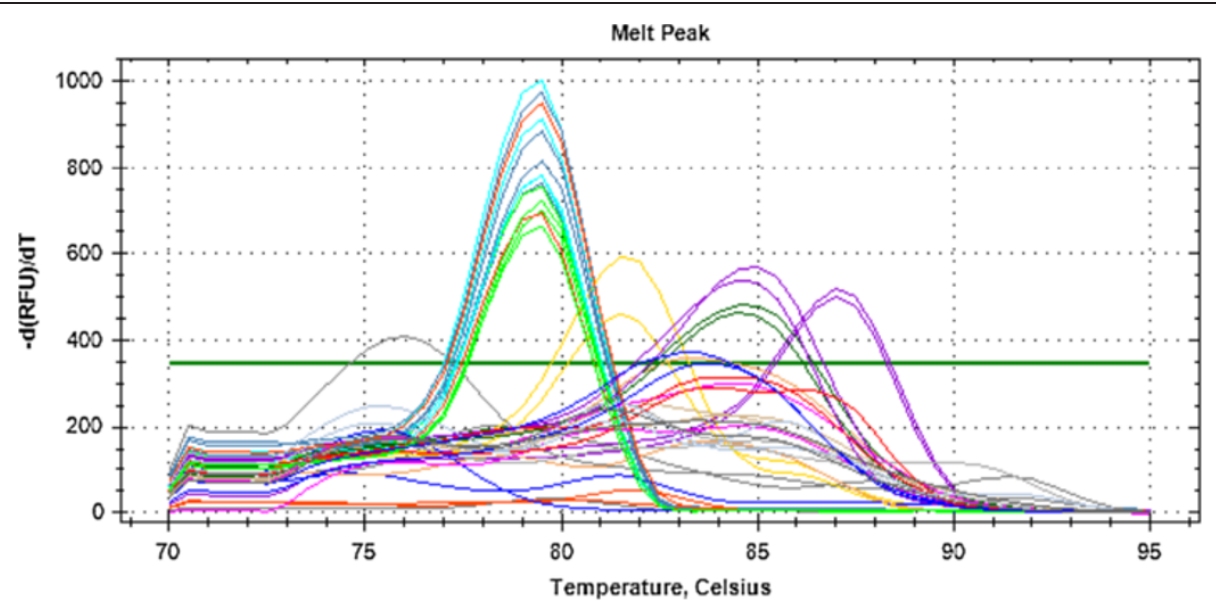

Figure 11 The melting curve analysis of the PCR products at the end of the amplification was done by measuring the Eva Green fluorescence by slow heating at $0.5^{\circ} \mathrm{Cs}^{-1}$ increments from 70 to $95^{\circ} \mathrm{C}$, with continuous fluorescence collection. Accordingly, a melting curve was generated at the end of the PCR amplification for monitoring the specificity of PCR reaction. It was found that a single peak (single product) at the expected melting temperature of PCR product, $T m 76-87^{\circ} \mathrm{C}$, was observed while no significant premature peaks were found indicating that primer dimers artifacts or incorrect amplification products were minimal and providing further evidence on the specific detection of the target mRNA genes.

compounds to induce apoptosis. Although, there was no effect on the level of $\mathrm{Bcl}-2$ expression in the treated HeLa and HepG2 cells with MBS extract, the Bax/Bcl-2 ratio in cells treated with MBS extract was high after 16h, for HeLa cells, and was high after 20h, for HepG2. Hence, this ratio may explain in part the susceptibility of the MBS-treated HeLa and HepG2 cells to apoptosis.

The upregulation of caspase 9 in HeLa and HepG2 cells was clear after $12 \mathrm{~h}$ of treatment with MBS extract. It is well known that caspase 9 can be activated by caspase 8 or can be activated independently on binding of cytochrome $c$ release from the mitochondria [56]. We assumed that the intrinsic apoptosis pathway induced by MBS extract in the treated cancer cells might be provoked via direct upregulation of caspase 9 gene, via the activation of caspase 8 by the extrinsic pathway, or via the upregulation of Bax gene. In addition, MBS extract induced the expression of caspase 7 gene in the treated HeLa and HepG2 cells after 12h. Caspase 7 can be activated by both extrinsic and intrinsic pathways of apoptosis. Moreover, caspase 7-dependent pathway without caspase-3 activation is recently considered as caspase-independent apoptosis pathway. And caspase 7 can activate caspase 12 which results in the induction of apoptosis during endoplasmic reticulum stress [57]. Therefore, the results of the current study disclosed a fact that MBS extract might induce apoptosis by different pathways. The reason behind these results is that we are dealing with a curde extract with a large number of different components that could trigger different pathways of apoptosis. Accordingly, using MBS extract might have advantage orver single active componnents in triggering two or three pathways of apoptosis simultaneously leading to vigorous induction of apoptosis. The induction of multi-pathway apoptosis usually leads to effective anticancer activity able to overcome any resistance that might issue from cancer cells against apoptotic signals or against one of the apopotitic pathways. For this reason, finding new natural anticancer products has increasingly become a favorable trend of treating cancer. In addition, the current results highlight the ability to isolate more than one effective cytotoxic component from MBS extract.

The regulatory proteins of cell cycle evaluated in the current study were chosen carefully in order to give further image on the underlying mechanisms for the observed G0/G1 arrest as well as apoptosis found in MBS-treated HeLa and HpeG2 cells. The studied markers were the cdk-activating proteins, namely cyclins and cdk-inhibitors, namely CKI or tumor suppressor proteins, such as $\mathrm{p} 27, \mathrm{p} 21$, and $\mathrm{p} 53$. Interestingly, MBS extract succeeded in inducing all the studied cdk-inhibitors, p21, p53, and p27 in HeLa cells while it induced only p53 in HepG2 cells. This is a clue for the cell typespecific interaction of MBS extract. This feature necessitates studying the cell growth- inhibiting activity of plants' extracts individually on different human cancer cell lines. The peak time for the induction of tumor suppressor proteins was after $16 \mathrm{~h}$. Therefore, after $20 \mathrm{~h}$, most affected cells died due to either cell cycle arrest or apoptosis. Upon comparing the current results with these of flow cytometry, it is obvious that both results are in harmony. Via flow cytometry, MBS extract caused slight and insignificant arrest in G1 phase of cell cycle of HepG2 cells but not HeLa cells. This feature was explained by the results of real time PCR. MBS extract 


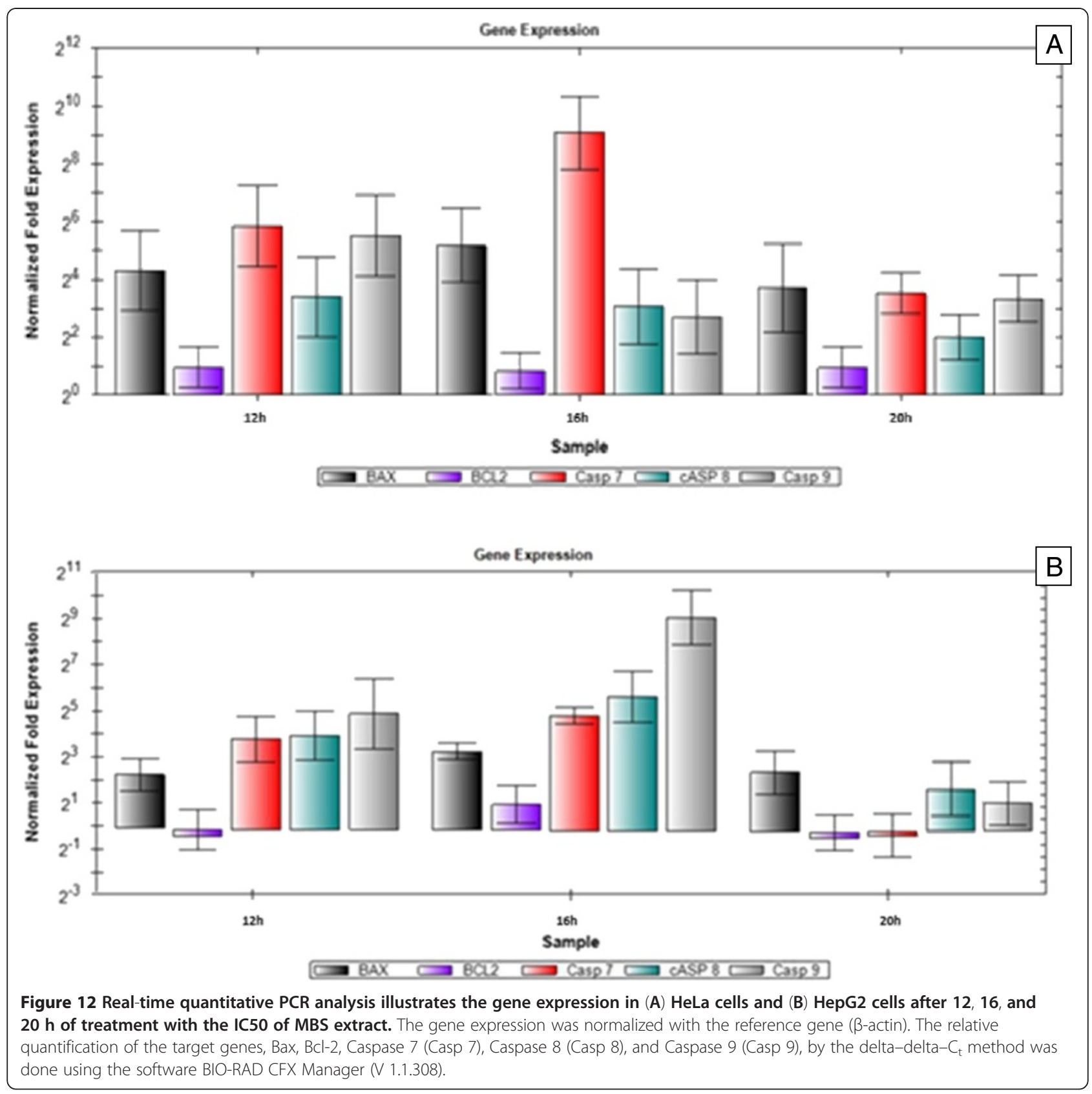

showed weak inducing capability to cdk-inhibitors, p21, p53, and p27 in HepG2 cells while it largely induced p21, p53, and p27 in HeLa cells.

The current findings of the cell cycle inhibitory effects of MBS extract showed weak or absent influence on the expression of cdk-activating cyclins. Instead, MBS extract showed remarkable induction and upsurge of cdkinhibitor proteins. Therefore, it is concluded that these cdk-inhibitor proteins are the main mechanism pursued by MBS extract to exert the G1 cell cycle arrest and ultimately the final fate, death of cells.

In addition, the current study revealed an interesting finding on MBS extract; it induced synthesis of TNF- $\alpha$ from cancerous cells. TNF- $\alpha$ can be the central link between the extract and its remarkable ability to induce cdkinhibitors and/or to downregulate cyclins. TNF- $\alpha$ was found to induce p21 (waf1) protein in tumor cells, and it also induces p21 binding to CDK $2 / 4$ and 6 complexes resulting in the inhibition of their activities [58]. This inhibition drives cells to G1 arrest. In addition, p27Kip1 was reported to induce caspase -dependent and -independent phases of cell death through TNF- $\alpha$ signaling [59].

In the current study, another antitumor cytokine was found to be secreted by tumor cells in response to MBS extract, namely IFN- $\beta$. Like TNF- $\alpha$, IFN- $\beta$ is most probably linked to the apoptotic and cell cycle slowing/ 


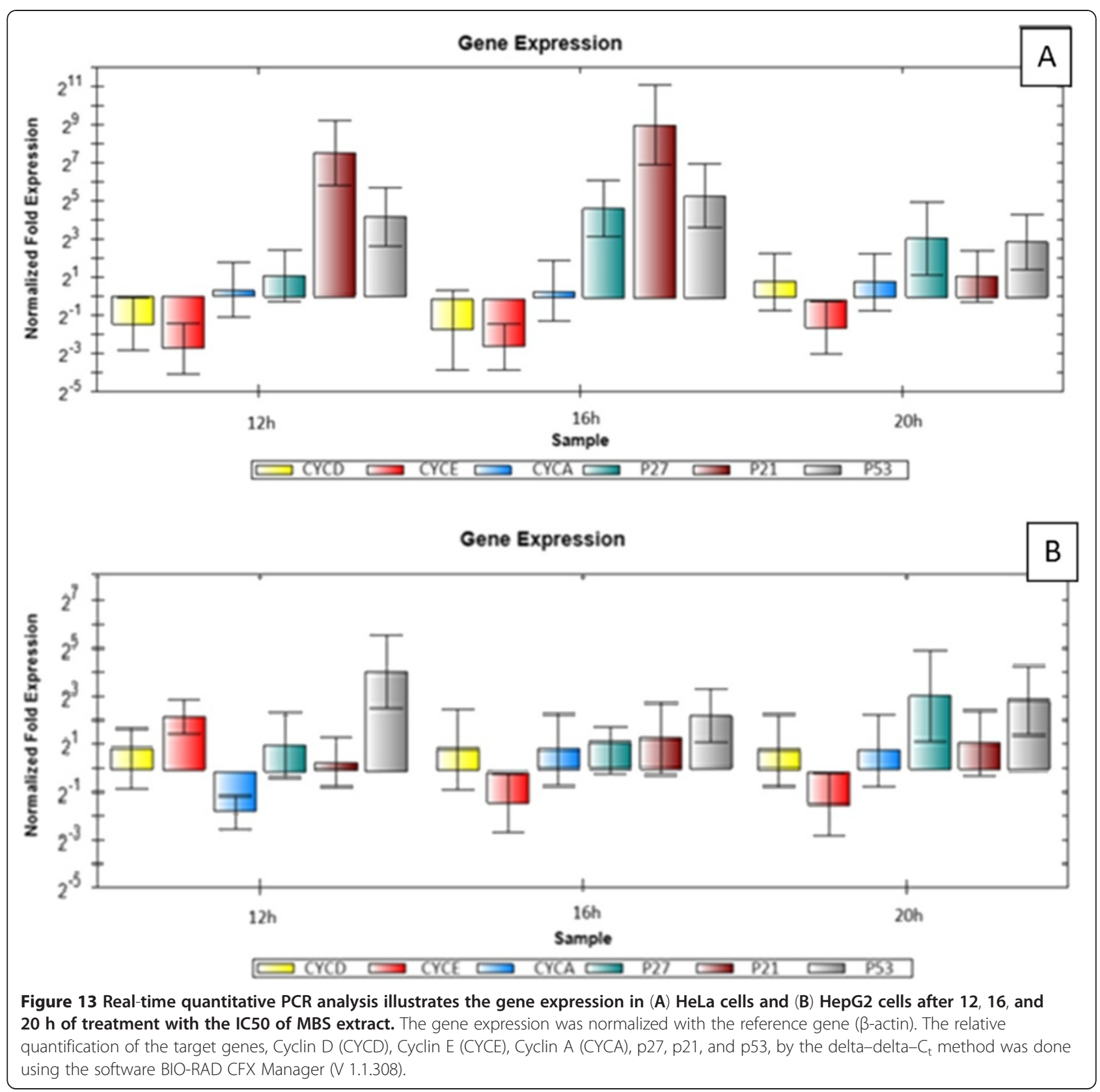

arresting potential of MBS. Interferons inhibit the growth of tumor cells by blocking the progression of their cell cycle via the upregulation of the cyclindependent kinase inhibitor p21 (waf1), [60]. Moreover,
TNF and IFN molecules were shown to synergistically induce a G1 arrest associated with reduced levels of cyclin D1 and cdk2, and increased expression of the cdk inhibitors p16INK4a, p21WAF1 and p27Kip1 [61]. In a

Table 10 A table summarizes the susceptibilty of the treated and untreated HeLa and HepG2 cells to apoptosis depending on the ratio between the pro-apoptotic protein (Bax) and the anti-apoptotic protein (Bcl-2)

\begin{tabular}{llllllll}
\hline Extract-cells & $\mathbf{B a x} / \mathbf{B c l}-\mathbf{2}$ untreated & $\mathbf{B a x} / \mathbf{B c l}-\mathbf{2}$ treated 12h & $\mathbf{P}$ value & $\mathbf{B a x} / \mathbf{B c l}-\mathbf{2}$ treated $\mathbf{1 6 h}$ & $\mathbf{P}$ value & $\mathbf{B a x} / \mathbf{B c l}-\mathbf{2}$ treated 20h & $\mathbf{P}$ value \\
\hline MBS-Hela & $0.31 \pm 0.03$ & $2.35 \pm 0.22$ & 0.004 & $10.71 \pm 2.75$ & 0.023 & $2.82 \pm 0.55$ & 0.016 \\
MBS-HepG2 & $0.64 \pm 0.06$ & $2.75 \pm 0.25$ & 0.005 & $4.09 \pm 1.01$ & 0.027 & $4.22 \pm 1.25$ & 0.038 \\
\hline
\end{tabular}

Note: the ratio was calculated as mean $\pm 2 \mathrm{SE}$.

The ratio of the treated cells was calculated after 12,16 , and $20 \mathrm{~h}$ of treatment with the IC50 of MBS extracts. 
recent study, IFN- $\beta$ signaling was shown to repress telomerase activity in ovarian cancer and this signaling was found to be mediated by p21(waf1) [62]. Interestingly, two previous studies proved the positive signaling pathway between IFN- $\beta$ and p53 and p21 proteins in inducing cell cycle arrest and apoptosis [63,64].

\section{Immunomodulatory activity of MBS extract}

The reason behind studying the immunomodulatory effect of MBS extract is that MBS is rich in flavonoids [65]. These compounds are able to stimulate $\mathrm{CD} 4^{+} \mathrm{T}$ lymphocytes that represent the major source of the IL-2 cytokine [66]. However, this study revealed a nonsignificant effect of MBS extract on IL-2 production from human PBMC. These results were supported by the findings of the proliferation assay which was performed on the same cells treated with MBS extract. The results showed negative effect of MBS extract on PBMC proliferation instead of a positive effect.

Cell-mediated immune response is an important aspect of host resistance to infection and cancer. It is thought to be tightly regulated by balance between type 1 cytokines (Th1) including IL-2, IFN- $\gamma$, TNF- $\alpha$, and IL-12 and the type 2 cytokines (Th2) such as IL-4, IL-6, and IL-10 [13]. Immunomodulators can be divided into main three groups, i.e., immunostimulating, immunosuppressive, and immunopolarizing agents, which all are useful for different therapeutic needs [67]. MBS extract was found to lack the immunostimulatory effect. Nevertheless, MBS extract was shown to shift the polarization of PBMC towards type 1 (Th1) rather than type 2 (Th2); this polarization determines the prognosis of many infectious diseases. And most importantly MBS-polarization can shift immune response from humoral to cell-mediated immunity (CMI) where the anti-tumor immune cytotoxicity lies. The immunomodulatory effect of MBS extract was evaluated by studying the production of IFN- $\gamma$ and IL-4 by PBMC cultured in vitro with MBS extract. IFN- $\gamma$ and IL-4 are key cytokines for the development of type 1 and type 2 immune responses, respectively [68]. The current study showed that MBS extract increased reamrakably IFN- $\gamma$ and decreased IL-4 levels in the supernatant of PBMC culture when compared with untreated (control) cells. The increase and the decrease in IFN- $\gamma$ and IL-4 levels, respectively, were dose-dependent; the highest increase in IFN- $\gamma$ or the highest decrease in IL4 levels were driven by the highest concentration used of MBS extract, $100 \mathrm{mg} / \mathrm{ml}$. The immunopolarizing effect of MBS extract towards Th1 immune response could be in agreement with a previous study which found that $\alpha$-tocopherol induces high secretion of IFN- $\gamma$ in vivo [69]. The role of IFN- $\gamma$ in enhancing antitumor immunity has been well proven by inducing $\mathrm{CD}^{+}$cells-based cellular cytotoxicity and by inducing abundant production of IL-12 which stimulates natural killer (NK) cells that act together with
$\mathrm{CD}^{+}$cells as the main immunological cytotoxicity defense line against tumors [70]. Moreover, ascorbic acid (vitamin C), the other major components of MBS extract, also induces IFN- $\gamma$ production by stimulating Th1 pathway cytokines [71,72]. In addition, the immunopolarizing effect of MBS extract shown in this study could be supported by a previous study which found a remarkable hepatoprotective role of mung bean aqueous extract in curing liver injury during hepatotoxicity [73]. The hypothesis behind the hepatoprotective action of mung bean aqueous extract could be due to its ability to induce the production of IFN$\gamma$. Interferon gamma is produced by certain subsets of natural killer $\mathrm{T}$ cells in the liver which are the primary mediators of antitumor responses [74,75]. Accordingly, in addition to the direct antitumor cytotoxicity and the induction of antitumor cytokines by MBS extract, the third antitumor mechanism of MBS could be attributed to the induction of IFN- $\gamma$ production and immunoplorization of immune resposne towards CMI and cellular cytotoxicity.

\section{Conclusion}

The cytotoxic effects of MBS extract were investigated thoroughly. The current study showed significant cytotoxic effects exerted by MBS extract against human cervical cancer cells and human hepatocarcinoma cells. The cytotoxicity of MBS extract to HeLa and HepG2 cells was shown to be hiihly selective. Moreover, MBS extract was found to act as a potent inducer for apoptosis in the treated human cancer cells via caspase-dependent, both extrinsic and intrinsic pathways, and may be caspaseindependent pathway. MBS extract induced apoptosis and cell cycle arrest in the treated human cancer cells via cell-type specific interactions. Cdk-inhibitor proteins (p21, p27, and p53) were the main mechanisms used by MBS extract to exert G1 cell cycle arrest and ultimately the final fate of cells, apoptosis.

In addition, MBS extract induced synthesis of TNF- $\alpha$ and IFN- $\beta$ from cancerous cells and this might be associated with the apoptotic and cell cycle slowing/arresting capability of MBS extract. Interestingly, MBS extract was shown to be an immunopolarizing agent by inducing IFN- $\gamma$ and inhibiting IL-4 production by PBMC. This triggers CMI and cellular cytotoxicity which are critical defense mechanisms against cancer, allergy, and different pathogens.

Taken together, the findings of the current study indicated that MBS extract is a highly promising cytotoxic agent by affecting either known or new targets in the anticancer chemotherapy. And these anticancer activities were thought to be driven by more than one component giving chance for MBS extract to exert strong, multi-mechanism, and synergistic anticancer and/or immunomodulatory effects. As the current study is unpredecented in exploring the anticancer activitieis and underlying mechanisms of MBS extract, further study is needed urgently to identify 
the bioactive compounds responsible for the discovered anticancer and immonumodaltory powerful and selective activities of MBS extract.

\section{Competing interests}

Authors declare that there are no competing interests associated with the current study.

\section{Authors' contributions}

RRH and ASA contributed equally to this work; RRH and ASA designed the work; FAJ provided vital reagents and analytical tools; $A S A$ and $F A B$ involved in editing the manuscript; $A S A, Z S$, and FA analyzed the data; FAB provided the financial support for this work; RRH wrote the manuscript. All authors have read and approved the final manuscript.

\section{Acknowledgements}

This study was supported by University Putra Malaysia which offered all required support whether financial or scientific.

\section{Author details}

'Department of Microbiology, College of Medicine, Baghdad University, Baghdad, Iraq. ${ }^{2}$ Institute of Bioscience, Universiti Putra Malaysia, 43400 UPM Serdang, Selangor Darul Ehsan, Malaysia. ${ }^{3}$ Department of Microbiology, College of Medicine, Al-Nahrain University, Baghdad, Iraq. ${ }^{4}$ Department of Medical Microbiology and Parasitology, Faculty of Medicine and Health Sciences, Universiti Putra Malaysia, 43400 UPM Serdang, Selangor Darul Ehsan, Malaysia. ${ }^{5}$ Clinical Microbiology Research Center, Ilam University of Medical Sciences, Ilam, Iran. ${ }^{6}$ Department of Food Science, Faculty of Food Science and Technology and Institute of Bioscience, Universiti Putra Malaysia, 43400 UPM Serdang, Selangor Darul Ehsan, Malaysia.

Received: 14 April 2012 Accepted: 31 October 2012

Published: 5 November 2012

\section{References}

1. Ullah MF, Khan MW: Food as medicine: potential therapeutic tendencies of plant derived polyphenolic compounds. Asian Pac J Cancer Prev 2008, 9(2):187-196.

2. Miean KH, Mohamed S: Flavonoid (Myricetin, Quercetin, Kaempferol, Luteolin, and Apigenin) Content of Edible Tropical Plants. J Agric Food Chem 2001, 49:3106-3112.

3. Win NN, Awale S, Esumi H, Tezuka Y, Kadota S: Novel anticancer agents, kayeassamins C-I from the flower of Kayea assamica of Myanmar. Bioorg Med Chem 2008, 16(18):8653-8660.

4. Youn U, Chen QC, Lee IS, Kim H, Yoo JK, Lee J, Na M, Min BS, Bae K: Two new lignans from the stem bark of Magnolia obovata and their cytotoxic activity. Chem Pharm Bull (Tokyo) 2008, 56(1):115-117.

5. Weng MS, Liao $\mathrm{CH}_{\text {, }}$ Chen $\mathrm{CN}$, Wu CL, Lin JK: Propolin $\mathrm{H}$ from Taiwanese propolis induces G1 arrest in human lung carcinoma cells. J Agric Food Chem 2007, 55(13):5289-5298.

6. Yagura T, Motomiya T, Ito M, Honda G, lida A, Kiuchi F, Tokuda H, Nishino H: Anticarcinogenic compounds in the Uzbek medicinal plant, Helichrysum maracandicum. Nat Med (Tokyo) 2008, 62(2):174-178.

7. Eum HA, Lee WY, Kim SH, Kim JY, Park SW, Lee JS, Choi SM, Pyo S, Kang MJ, Min YD, et al: Anti-inflammatory activity of CML-1: an herbal formulation. Am J Chin Med 2005, 33(1):29-40.

8. Ha KT, Lee TK, Kwak KH, Kim JK, Kim DI, Choi DY, Kim CH: Inhibitory effect of Cho-Deung-San on human aortic smooth muscle cell migration induced by TNF-alpha through inhibition of matrix metalloproteinase-2 and -9 activity. Vascul Pharmacol 2004, 41(3):83-90.

9. Zhou JR, Yu L, Zhong Y, Blackburn GL: Soy phytochemicals and tea bioactive components synergistically inhibit androgen-sensitive human prostate tumors in mice. J Nutr 2003, 133(2):516-521.

10. Dixon RA: Progress natural products and plant disease resistance. Nature 2001, 411:843-847.

11. Lawson BR, Belkowski SM, Whitesides JF, Davis P, Lawson JW: Immunomodulation of murine collagen-induced arthritis by N. Ndimethylglycine and a preparation of Perna canaliculus. BMC Complement Altern Med 2007, 7:20.

12. Waterhouse PM, Wang MB, Lough $\mathrm{T}$ : Gene silencing as an adaptive defence against viruses. Nature 2001, 411(6839):834-842.
13. Roitt IM, Delves PJ: Roitt's essential immunology. 10th edition. Massachusetts, USA: Blackwell Science Ltd; 2001.

14. Williams LAD, Reese PB: Biologically active natural products for the 21st century, 2006. Trivandrum, Kerala, India: Research Signpost; 2006.

15. Stratil P, Klejdus B, Kuban V: Determination of total content of phenolic compounds and their antioxidant activity in vegetables-evaluation of spectrophotometric methods. J Agric Food Chem 2006, 54(3):607-616.

16. Piazza GA, Rahm AL, Krutzsch M, Sperl G, Paranka NS, Gross PH, Brendel K, Burt RW, Alberts DS, Pamukcu R, et al: Antineoplastic drugs sulindac sulfide and sulfone inhibit cell growth by inducing apoptosis. Cancer Res 1995, 55(14):3110-3116.

17. Cory AH, Owen TC, Barltrop JA, Cory JG: Use of an aqueous soluble tetrazolium/formazan assay for cell growth assays in culture. Cancer Commun 1991, 3(7):207-212.

18. Sriwanthana $B$, Chavalittumrong $P$ : In vitro effect of Derris scandens on normal lymphocyte proliferation and its activities on natural killer cells in normals and HIV-1 infected patients. J Ethnopharmacol 2001, 76(1):125-129.

19. Lin CC, Ng LT, Hsu FF, Shieh DE, Chiang LC: Cytotoxic effects of Coptis chinensis and Epimedium sagittatum extracts and their major constituents (berberine, coptisine and icarin) on hepatoma and leukaemia cell growth. Clin Exp Pharmacol Physiol 2004, 31:65-69.

20. Mena-Rejon G, Caamal-Fuentes E, Cantillo-Ciau Z, Cedillo-Rivera R, FloresGuido J, Moo-Puc R: In vitro cytotoxic activity of nine plants used in Mayan traditional medicine. J Ethnopharmacol 2009, 121(3):462-465.

21. Tanabe S, Kinuta Y, Yasumatsu H, Takayanagi M, Kobayashi S, Takido N, Sugiyama M: Effects of Citrus unshiu powder on the cytokine balance in peripheral blood mononuclear cells of patients with seasonal allergic rhinitis to pollen. Biosci Biotechnol Biochem 2007, 71(11):2852-2855.

22. Kang JX, Liu J, Wang J, He C, Li FP: The extract of huanglian, a medicinal herb, induces cell growth arrest and apoptosis by upregulation of interferon-beta and TNF-alpha in human breast cancer cells. Carcinogenesis 2005, 26(11):1934-1939.

23. Buolamwini JK, Adjei AA: Novel anticancer drug protocols. Totowa, NJ: Humana Press; 2003

24. Siddik ZH: Checkpoint controls and targets in cancer therapy. Totowa, N.J.; London: Humana; 2009.

25. Otsuki Y, Li Z, Shibata MA: Apoptotic detection methods-from morphology to gene. Prog Histochem Cytochem 2003, 38(3):275-339.

26. Bustin SA, Benes V, Garson JA, Hellemans J, Huggett J, Kubista M, Mueller R, Nolan T, Pfaffl MW, Shipley GL, et al: The MIQE guidelines: minimum information for publication of quantitative real-time PCR experiments. Clin Chem 2009, 55(4):611-622.

27. Pfaffl $M W: A$ new mathematical model for relative quantification in realtime RT-PCR. Nucleic Acids Res 2001, 29(9):e45.

28. Marzo I, Naval J: BCl-2 family members as molecular targets in cancer therapy. Biochem Pharmacol 2008, 76(8):939-946.

29. Wild CP, Montesano R: A model of interaction: aflatoxins and hepatitis viruses in liver cancer aetiology and prevention. Cancer Lett 2009, 286(1):22-28.

30. Bhatla N, Joseph E: Cervical cancer prevention \& the role of human papillomavirus vaccines in India. Indian J Med Res 2009, 130(3):334-340.

31. Cseke LJ: Natural products from plants. 2nd edition. Boca Raton, FL: CRC/ Taylor \& Francis; 2006.

32. Fernandez-Orozco R, Frias J, Zielinski H, Piskula MK, Kozlowska H, VidalValverde C: Kinetic study of the antioxidant compounds and antioxidant capacity during germination of Vigna radiata $\mathrm{cv}$. emmerald, Glycine max cv. jutro and Glycine max cv. merit. Food Chem 2008, 111:622-630.

33. Sawa T, Nakao M, Akaike T, Ono K, Maeda H: Alkylperoxyl radicalscavenging activity of various flavonoids and other phenolic compounds: implications for the anti-tumor-promoter effect of vegetables. J Agric Food Chem 1999, 47(2):397-402.

34. Ricciarelli R, Zingg JM, Azzi A: The 80th anniversary of vitamin E: beyond its antioxidant properties. Biol Chem 2002, 383(3-4):457-465.

35. Nagibina MV, Neifakh EA, Krylov VF, Braginskii DM, Kulagina MG: The treatment of pneumonias in influenza using antioxidants. Ter Arkh 1996, 68(11):33-35.

36. Pertseva NG, Ananenko AA, Malinovskaia W, Klembovskii Al, Burova V, Meshkova EN, Kleimenova NV: The effect of reaferon and alphatocopherol on lipid peroxidation in experimental influenza. Vopr Virusol 1995, 40(2):59-62. 
37. Lee E, Choi MK, Lee YJ, Ku JL, Kim KH, Choi JS, Lim SJ: Alpha-tocopheryl succinate, in contrast to alpha-tocopherol and alpha-tocopheryl acetate, inhibits prostaglandin E2 production in human lung epithelial cells. Carcinogenesis 2006, 27(11):2308-2315.

38. Xu WH, Dai Q, Xiang YB, Zhao GM, Ruan ZX, Cheng JR, Zheng W, Shu XO: Nutritional factors in relation to endometrial cancer: a report from a population-based case-control study in Shanghai, China. Int J Cancer 2007, 120(8):1776-1781.

39. Ramanathapuram LV, Kobie JJ, Bearss D, Payne CM, Trevor KT, Akporiaye ET: alpha-Tocopheryl succinate sensitizes established tumors to vaccination with nonmatured dendritic cells. Cancer Immunol Immunother 2004, 53(7):580-588.

40. Huang JP, Zhang M, Holman CD, Xie X: Dietary carotenoids and risk of breast cancer in Chinese women. Asia Pac J Clin Nutr 2007, 16:437-442

41. Iqbal Ahmed CM, Johnson HM: Interferon gene therapy for the treatment of cancer and viral infections. Drugs Today (Barc) 2003, 39(10):763-766.

42. Bartee $E$, McFadden G: Human cancer cells have specifically lost the ability to induce the synergistic state caused by tumor necrosis factor plus interferon-beta. Cytokine 2009, 47(3):199-205.

43. Brierley MM, Fish EN: Review: IFN-alpha/beta receptor interactions to biologic outcomes: understanding the circuitry. J Interferon Cytokine Res 2002, 22(8):835-845.

44. Rosfjord EC, Dickson RB: Growth factors, apoptosis, and survival of mammary epithelial cells. J Mammary Gland Biol Neoplasia 1999, 4(2):229-237.

45. Yu W, Jia L, Park SK, Li J, Gopalan A, Simmons-Menchaca M, Sanders BG, Kline K: Anticancer actions of natural and synthetic vitamin E forms: RRRalpha-tocopherol blocks the anticancer actions of gamma-tocopherol. Mol Nutr Food Res 2009, 53(12):1573-1581.

46. Kanai K, Kikuchi E, Mikami S, Suzuki E, Uchida Y, Kodaira K, Miyajima A, Ohigashi T, Nakashima J, Oya M: Vitamin E succinate induced apoptosis and enhanced chemosensitivity to paclitaxel in human bladder cancer cells in vitro and in vivo. Cancer Sci 2010, 101(1):216-223.

47. Belin S, Kaya F, Duisit G, Giacometti S, Ciccolini J, Fontes M: Antiproliferative effect of ascorbic acid is associated with the inhibition of genes necessary to cell cycle progression. PLoS One 2009, 4(2):e4409.

48. Scarfi S, Magnone M, Ferraris C, Pozzolini M, Benvenuto F, Benatti U, Giovine M: Ascorbic acid pre-treated quartz stimulates TNF-alpha release in RAW 264.7 murine macrophages through ROS production and membrane lipid peroxidation. Respir Res 2009, 10:25.

49. Kummalue T, Oc P, Jiratchariyakul W, Chanchai M, Pattanapanyasat K, Sukapirom K, lemsri S: Antiproliferative effect of Erycibe elliptilimba on human breast cancer cell lines. J Ethnopharmacol 2007, 110(3):439-443.

50. Swanton C: Cell-cycle targeted therapies. Lancet Oncol 2004, 5(1):27-36

51. Kandaswami C, Lee LT, Lee PP, Hwang JJ, Ke FC, Huang YT, Lee MT: The antitumor activities of flavonoids. In Vivo 2005, 19(5):895-909.

52. Tsuda H, Ohshima Y, Nomoto H, Fujita K, Matsuda E, ligo M, Takasuka N, Moore MA: Cancer prevention by natural compounds. Drug Metab Pharmacokinet 2004, 19(4):245-263.

53. Haupt S, Berger M, Goldberg Z, Haupt Y: Apoptosis - the p53 network. J Cell Sci 2003, 116(Pt 20):4077-4085.

54. Erhardt P: Apoptosis. New York, NY: Humana Press; 2009.

55. Saito M, Korsmeyer SJ, Schlesinger PH: BAX-dependent transport of cytochrome c reconstituted in pure liposomes. Nat Cell Biol 2000 , 2(8):553-555.

56. Green DR, Reed JC: Mitochondria and apoptosis. Science 1998, 281(5381):1309-1312.

57. Rao RV, Hermel E, Castro-Obregon S, del Rio G, Ellerby LM, Ellerby HM, Bredesen DE: Coupling endoplasmic reticulum stress to the cell death program. Mechanism of caspase activation. J Biol Chem 2001, 276(36):33869-33874.

58. Moneo V, del Valle Guijarro M, Link W, Carnero A: Overexpression of cyclin D1 inhibits TNF-induced growth arrest. J Cell Biochem 2003, 89(3):484-499.

59. Jaruga-Killeen $E$, Rayford W: TNF receptor 1 is involved in the induction of apoptosis by the cyclin dependent kinase inhibitor p27Kip1 in the prostate cancer cell line PC-3. FASEB J 2005, 19(1):139-141.

60. Hobeika AC, Etienne W, Torres BA, Johnson HM, Subramaniam PS: IFNgamma induction of p21(WAF1) is required for cell cycle inhibition and suppression of apoptosis. J Interferon Cytokine Res 1999, 19(12):1351-1361.

61. Dormond O, Lejeune FJ, Ruegg C: Modulation of cdk2, cyclin D1, p16INK4a, p21WAF and p27Kip1 expression in endothelial cells by TNF/ IFN gamma. Anticancer Res 2002, 22(6A):3159-3163.
62. Lee J, Kim SS: The function of p27 KIP1 during tumor development. Exp Mol Med 2009, 41(11):765-771.

63. Hamner JB, Sims TL, Cutshaw A, Dickson PV, Rosati S, McGee M, Ng CY, Davidoff AM: The efficacy of combination therapy using adenoassociated virus--interferon beta and trichostatin $A$ in vitro and in a murine model of neuroblastoma. J Pediatr Surg 2008, 43(1):177-182. discussion 182-173.

64. Sasaki M, Ikeda H, Sato Y, Nakanuma Y: Proinflammatory cytokine-induced cellular senescence of biliary epithelial cells is mediated via oxidative stress and activation of ATM pathway: a culture study. Free Radic Res 2008, 42(7):625-632.

65. Arapitsas P, Sjoberg PJR, Turner C: Characterisation of anthocyanins in red cabbage using high resolution liquid chromatography coupled with photodiode array detection and electrospray ionization-linear ion trap mass spectrometry. Food Chem 2008, 109:219-226.

66. Maghraby AS, Shalaby N, Abd-Alla HI, Ahmed SA, Khaled HM, Bahgat MM: Immunostimulatory effects of extract of Pulicaria crispa before and after Schistosoma mansoni infection. Acta Pol Pharm 2010, 67(1):75-79.

67. Werner $\mathrm{GH}$, Jolles P: Immunostimulating agents: what next? A review of their present and potential medical applications. Eur J Biochem 1996, 242(1):1-19.

68. Kobayashi H, Nagasawa T, Aramaki M, Mahanonda R, Ishikawa I: Individual diversities in interferon gamma production by human peripheral blood mononuclear cells stimulated with periodontopathic bacteria. J Periodontal Res 2000, 35(6):319-328.

69. Koizumi T, Bando N, Terao J, Yamanishi R: Feeding with both betacarotene and supplemental alpha-tocopherol enhances type 1 helper $T$ cell activity among splenocytes isolated from D011.10 mice. Biosci Biotechnol Biochem 2006, 70(12):3042-3045.

70. Xu Z, Hurchla MA, Deng H, Uluckan O, Bu F, Berdy A, Eagleton MC, Heller EA, Floyd DH, Dirksen WP, et al: Interferon-gamma targets cancer cells and osteoclasts to prevent tumor-associated bone loss and bone metastases. J Biol Chem 2009, 284(7):4658-4666.

71. Fukuzawa K, Kogure K, Morita M, Hama S, Manabe S, Tokumura A: Enhancement of nitric oxide and superoxide generations by alphatocopheryl succinate and its apoptotic and anticancer effects. Biochemistry (Mosc) 2004, 69(1):50-57.

72. Chang HH, Chen CS, Lin JY: High dose vitamin C supplementation increases the Th1/Th2 cytokine secretion ratio, but decreases eosinophilic infiltration in bronchoalveolar lavage fluid of ovalbumin-sensitized and challenged mice. J Agric Food Chem 2009, 57(21):10471-10476.

73. Wu SJ, Wang JS, Lin CC, Chang CH: Evaluation of hepatoprotective activity of legumes. Phytomedicine 2001, 8(3):213-219.

74. Subleski JJ, Wiltrout RH, Weiss JM: Application of tissue-specific NK and NKT cell activity for tumor immunotherapy. J Autoimmun 2009, 33(3-4):275-281.

75. Uemura A, Takehara T, Miyagi T, Suzuki T, Tatsumi T, Ohkawa K, Kanto T, Hiramatsu N, Hayashi N: Natural killer cell is a major producer of interferon gamma that is critical for the IL-12-induced anti-tumor effect in mice. Cancer Immunol Immunother 2010, 59(3):453-463.

\section{doi:10.1186/1472-6882-12-208}

Cite this article as: Hafidh et al:: Novel molecular, cytotoxical, and immunological study on promising and selective anticancer activity of Mung bean sprouts. BMC Complementary and Alternative Medicine 2012 $12: 208$.

\section{Submit your next manuscript to BioMed Central and take full advantage of:}

- Convenient online submission

- Thorough peer review

- No space constraints or color figure charges

- Immediate publication on acceptance

- Inclusion in PubMed, CAS, Scopus and Google Scholar

- Research which is freely available for redistribution 